\title{
Tryptamine-based derivatives as Transient Receptor Potential Melastatin type-8 (TRPM8) channel modulators
}

Alessia Bertamino $^{\mathrm{a}, \S}$, Carmine Ostacolo $^{\mathrm{b}, \S}$, Paolo Ambrosino ${ }^{\mathrm{c}, \S}$, Simona Musella $^{\mathrm{b}}$, Veronica Di Sarno ${ }^{\mathrm{a}}$, Tania Ciaglia ${ }^{\mathrm{a}}$, Maria Virginia Soldovieri ${ }^{\mathrm{c}}$, Nunzio Iraci ${ }^{\mathrm{a}}$, Asia Fernandez Carvajal ${ }^{\mathrm{d}}$, Roberto de la Torre $^{\mathrm{d}}$, Antonio Ferrer-Montiel ${ }^{\mathrm{d}}$, Rosario Gonzalez Muniz ${ }^{\mathrm{e}}$, Ettore Novellino ${ }^{\mathrm{b}}$, Maurizio Taglialatela ${ }^{\mathrm{c}}$, Pietro Campiglia ${ }^{\mathrm{a}^{*}}$, Isabel Gomez-Monterrey ${ }^{\mathrm{b} *}$

a Department of Pharmacy, University of Salerno, Via G. Paolo II 132, 84084, Fisciano (SA), Italy

${ }^{\mathrm{b}}$ Department of Pharmacy, University Federico II of Naples, Via D. Montesano 49, 80131, Naples, Italy

${ }^{c}$ Department of Medicine and Health Science, University of Molise, Via de Sanctis, 86100, Campobasso, Italy

${ }^{d}$ Institute of Molecular and Cellular Biology, University Miguel Hernández of Elche, 032020, Elche (Alicante), Spain

${ }^{\mathrm{e}}$ Institute of Medicinal Chemistry, IQM-CSIC, c/ Juan de la Cierva 3, 28006, Madrid, Spain 


\begin{abstract}
Pharmacological modulation of the transient receptor potential melastatin type 8 (TRPM8) is currently under investigation as a new approach mainly for the treatment of pain. In this study, a series of $\mathrm{N}$-substituted tryptamines was prepared to explore the structural requirements determining TRPM8 modulation. As a result of a fluorescence-based screening assay, we identified two compounds acting as an activator (2-(1H-indol-3-yl)-N-(4-phenoxybenzyl) ethanamine, compound 21) or an inhibitor (N,N-dibenzyl-2-(1H-indol-3-yl) ethanamine, compound 12) of calcium influx in HEK293 cells. In patch-clamp recordings, compound 21 displayed a significantly higher potency $\left(\mathrm{EC}_{50}=40 \pm 4 \mu \mathrm{M}\right)$ and a similar efficacy when compared to menthol; by contrast, compound $\mathbf{1 2}$ produced a concentrationdependent inhibition of menthol-induced TRPM8 currents $\left(\mathrm{IC}_{50}=367 \pm 24 \mathrm{nM}\right)$. Molecular modelling studies using a homology model of a single TRPM8 subunit identified a putative binding site located between the VSD and the TRP box, disclosing two different binding modes for the agonist and the antagonist.
\end{abstract}




\section{Introduction}

Transient receptor potential melastatin type-8 (TRPM8) is a transmembrane, non-selective $\mathrm{Ca}^{2+}$ permeable cation channel, ${ }^{1}$ considered as the major sensor for peripheral innocuous cool and its modulation contributes to a wide range of physiological and pathophysiological processes. One of the most investigated effects produced by TRPM8 modulation is the analgesia against chronic and neuropathic pain: in fact, it has been reported that peripheral and central activation of TRPM8 induces analgesia, specifically reversing the sensitization of the behavioral reflexes elicited by peripheral nerve injury. ${ }^{2}$ Notably, both TRPM8 agonists and antagonists exert analgesic effects: in particular, while TRPM8 agonists produce profound analgesia ${ }^{2}$ at very low concentrations, even greater effects have been reported for TRPM8 antagonists. ${ }^{3}$ This analgesia modulation represents a novel approach in a largely unmet therapeutic need. ${ }^{4}$ Moreover, many studies have recently revealed novel potential pharmacological implications for TRPM8 modulators. For example, TRPM8 agonists have been proposed as useful diagnostic and therapeutic tools for the treatment of prostate cancer and benign prostate hyperplasia (BPH). ${ }^{5,6}$ In fact the activation of TRPM8 receptors enhances apoptosis in prostate carcinoma cells, highlighting a potential involvement of this channel in androgen-responsive prostate cancer cell growth. Apart from androgen-sensitive prostate cancer, TRPM8 is abnormally over-expressed in other tumor malignancies, like breast cancer, ${ }^{7,8}$ human pancreatic adenocarcinoma, 9 and skin melanoma cells. ${ }^{10}$ Concurrently, TRPM8 blockers have been investigated for the treatment of overactive and painful bladder syndromes. ${ }^{11}$ In particular, N-(3-Aminopropyl)-2-[(3methylphenyl)methoxy]-N-(2-thienylmethyl) benzamide (AMTB), a well-recognized TRPM8 antagonist, can attenuate the bladder micturition reflex and the nociceptive reflex response in the rat, thus decreasing the frequency of volume-induced bladder contraction. ${ }^{12}$ Finally, TRPM8 modulators could be of interest in treating dry eye syndrome and excessive lacrimation dysfunction, due to extensive TRPM8 expression in corneal afferent neurons. ${ }^{13,14}$ 
For these reasons, increasing efforts have been dedicated, both by academia and industry, to the design of TRPM8 ligands starting from different structural scaffolds. ${ }^{15-22}$ Most of the compounds described in the literature showed high potency on TRPM8 channels, although they also show agonistic and/or antagonistic properties towards other TRP receptors, such as TRPA1 and TRPV1

channels. ${ }^{23,24}$ Recently, some indole alkaloids have been identified, ${ }^{25}$ resulting in potent antagonists with a pronounced selectivity for TRPM8 when compared to TRPA1 or TRPV1 channels. Also 5substituted tryptamines have been studied as potent TRPM8 blockers. ${ }^{26}$ In addition, in a previous work we demonstrated that the potency of TRPM8 ligands could be modulated varying substituents on the nitrogen group of the aminoisoxazole scaffold. ${ }^{21}$

On the basis of these findings, we synthesized a focused library of 18 tryptamine-based compounds and tested their activity as TRPM8 modulators by performing a fluorescence-based assay and patch-clamp recordings. Pharmacological activity was rationalized by molecular modelling studies defining basic structural requirements for TRPM8 agonism and antagonism. In addition, computational studies allowed the identification of a putative binding site for tryptamine-based TRPM8 modulators.

\section{Results and Discussion}

\section{Chemistry}

Derivatives 4-12 were synthesized according the experimental procedure showed in Scheme 1. A subset of compounds (4-7, scheme 1) was prepared from the N-1 substituted intermediates 2 and 3. Reaction of 3-(2-bromoethyl)-1H-indole (1) with methyl iodide or 4-phenylbenzyl iodide in DCM/DMF using $\mathrm{NaH}$ as a base, led to derivatives 2 and $\mathbf{3}$ with $67 \%$ and $61 \%$ yields, respectively. The 4-phenylbenzyl iodide (III, see supplementary information, scheme S1), used in the formation of 
intermediate $\mathbf{3}$, was previously prepared from the corresponding biphenyl-4-carboxylic acid as reported elsewhere. ${ }^{27}$

Scheme 1. Synthesis of the N, 2-substituted indolethanamine derivatives 4-12

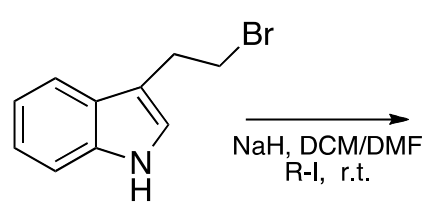

1

$\mathrm{R}^{\prime} \mathrm{NH}_{2}$, THF, TEA, $\left(\mathrm{CH}_{3} \mathrm{COO}\right)_{2} \mathrm{Pd}$
$\mathrm{mW} 100^{\circ} \mathrm{C}, 20 \mathrm{~min}$

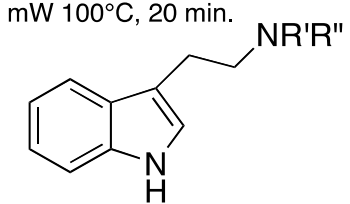

8-12<smiles>CCc1cccc2ccccc12</smiles>

8<smiles>Cc1cccc2ncccc12</smiles>

10<smiles>Cc1ccc2ccccc2c1</smiles>

9<smiles>Cc1cccc2cnccc12</smiles>

11

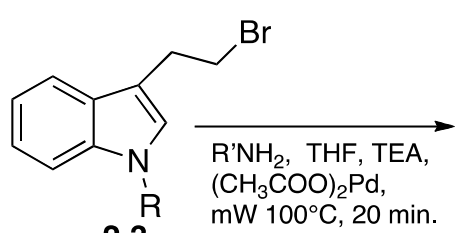

2,3

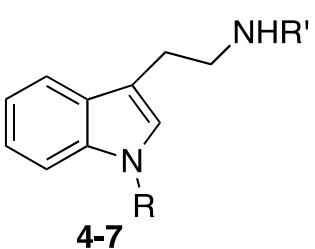

4-7

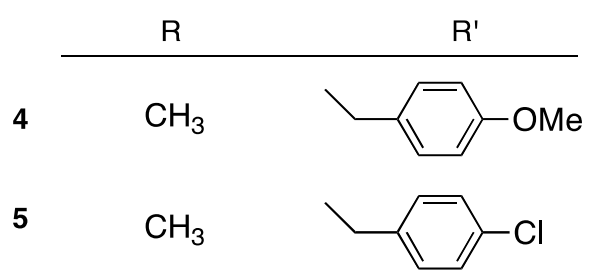

6<smiles>CCc1ccc(-c2ccccc2)cc1</smiles>

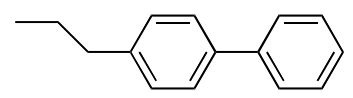

$R^{\prime}=R^{\prime \prime}=$

12

Nucleophilic displacement of the bromine atom of $\mathbf{1}, \mathbf{2}$ and $\mathbf{3}$ by different commercially available amines was performed in THF/TEA using palladium acetate as a catalyst. Under microwave conditions the final compounds 4-12 were obtained in 55-75\% yield.

A different strategy was used for the synthesis of compounds 14-22, which employed tryptamine $\mathbf{1 3}$ as starting material (Scheme 2). Compound $\mathbf{1 4}$ was obtained as racemic mixture by nucleophilic substitution reaction of the tosyl derivative of the (1,2,3,4-tetrahydronaphthalen-4yl)methanol (VI) with tryptamine (13). This intermediate VI has been synthesized by reducing the 1,2,3,4-tetrahydronaphthalene-1-carboxylic acid with lithium aluminium hydride, followed by 
tosylation with 4-methylbenzene-1-sulfonyl chloride (see supplementary information, scheme S1). ${ }^{28}$

Reductive amination of different commercially available aldehydes with the tryptamine, using sodium triacetoxyborohydride as reductive agent gave the final compounds $\mathbf{1 5 - 2 1}$ in $51 \%-85 \%$ yields (Scheme 2). ${ }^{21}$

Finally, treatment of derivative $\mathbf{2 1}$ with methyl iodide using $\mathrm{NaH}$ as a base allowed us to obtained the dimethyl derivative $\mathbf{2 2}$ in $37 \%$ yield.

Scheme 2. Synthesis of the N, 2-substituted indolethanamine derivatives 14-22<smiles>NCCc1c[nH]c2ccccc12</smiles><smiles>c1ccc2c(c1)CCCC2CNCCc1c[nH]c2ccccc12</smiles>

13<smiles>[R]NCCc1c[nH]c2ccccc12</smiles>

15-21<smiles>CCc1ccc(Oc2ccccc2)cc1</smiles><smiles>[O-][N+]([O-])(O)O</smiles><smiles>CN(CCc1cn(C)c2ccccc12)Cc1ccc(Oc2ccccc2)cc1</smiles> 


\section{Screening of the activity of the synthesized compounds by $\mathrm{Ca}^{2+}$-imaging experiments}

To investigate the potential agonistic or antagonistic properties on TRPM8 channels, all synthesized compounds were tested at three different concentrations $(0.5,5$ and $50 \mu \mathrm{M})$ by in vitro $\mathrm{Ca}^{2+}$ fluorometric assays experiments using Fluo4-NW in HEK293 cells stably expressing mouse TRPM8 channels. The results obtained are normalized to the effects prompted by $100 \mu \mathrm{M}$ of the canonical agonist menthol ${ }^{29}$ or by $10 \mu \mathrm{M}$ of the TRPM8 antagonist AMTB $+100 \mu \mathrm{M}$ menthol, ${ }^{11}$ whose effects were reported as $+100 \%$ (activation) or $-100 \%$ (inhibition), respectively (Figures $1 \mathrm{~A}$ and 1B).

As reported in Figure 1A, compounds $\mathbf{4}$ and $\mathbf{5}$ showed agonist activity at high concentration (50 $\mu \mathrm{M})$, being about 2-fold more effective than menthol. At the same concentration, the presence of the sterically hindered biphenyl ethyl group on the amine moiety (6), led to slight loss of efficacy in comparison to $\mathbf{4}$ and $\mathbf{5}$, maintaining an efficacy similar to menthol. Interestingly, introduction of a sterically hindered group at N-1 indole position, such as a biphenyl methyl group, together with increased flexibility of the substituent on the amine moiety (7 versus 4 or 5 ) maintained agonistic efficacy .

The non-substituted N-1 indole derivatives (8-21) were quite productive. A direct linkage of the amine moiety with different bulky aromatic groups, such as naphthalene and quinolines, gives compounds 8-11 unable to act as TRPM8 modulators (Figures 1A and 1B). By contrast, the tertiary amine obtained by derivatization of tryptamine with a benzyl moiety (12) proved to be an effective and potent antagonist. Introduction of a methylene spacer between amine group and bulky aryl moiety in $\mathbf{8}$ led to the potent agonist $\mathbf{1 5}$, which showed to be 3 -fold more effective than menthol at $50 \mu \mathrm{M}$. Introduction of substituents at position 2 of naphthalene ring, such as $\mathrm{OMe}(\mathbf{1 6})$ and $\mathrm{OH}(\mathbf{1 7})$ induced a shift from agonist to antagonistic activity for these derivatives at high concentration (Fig. 1 B). A 
similar effect was observed when the bicyclic system modification involves changes in the electronic nature of the ring (14) or an increase in ring size (18). In addition, tryptamine benzyl derivatives 19 and 20 lost the agonistic activity shown by the methylated analogue 4 .

Notably, compound 21 bearing a $p$-methoxybenzyl group showed significant agonist activity at $0.5 \mu \mathrm{M}$, with a similar efficacy to that of menthol. At $50 \mu \mathrm{M}$, the efficacy of derivative 21 was nearly 3 -fold higher than that of menthol. Conversion of this compound to its N-methyl-2-(1-methyl-1Hindol-3-yl)-derivative (22) shifted the agonistic activity to antagonism, with an efficacy comparable to that of derivative 12, at all tested concentrations (Figure 1B). 


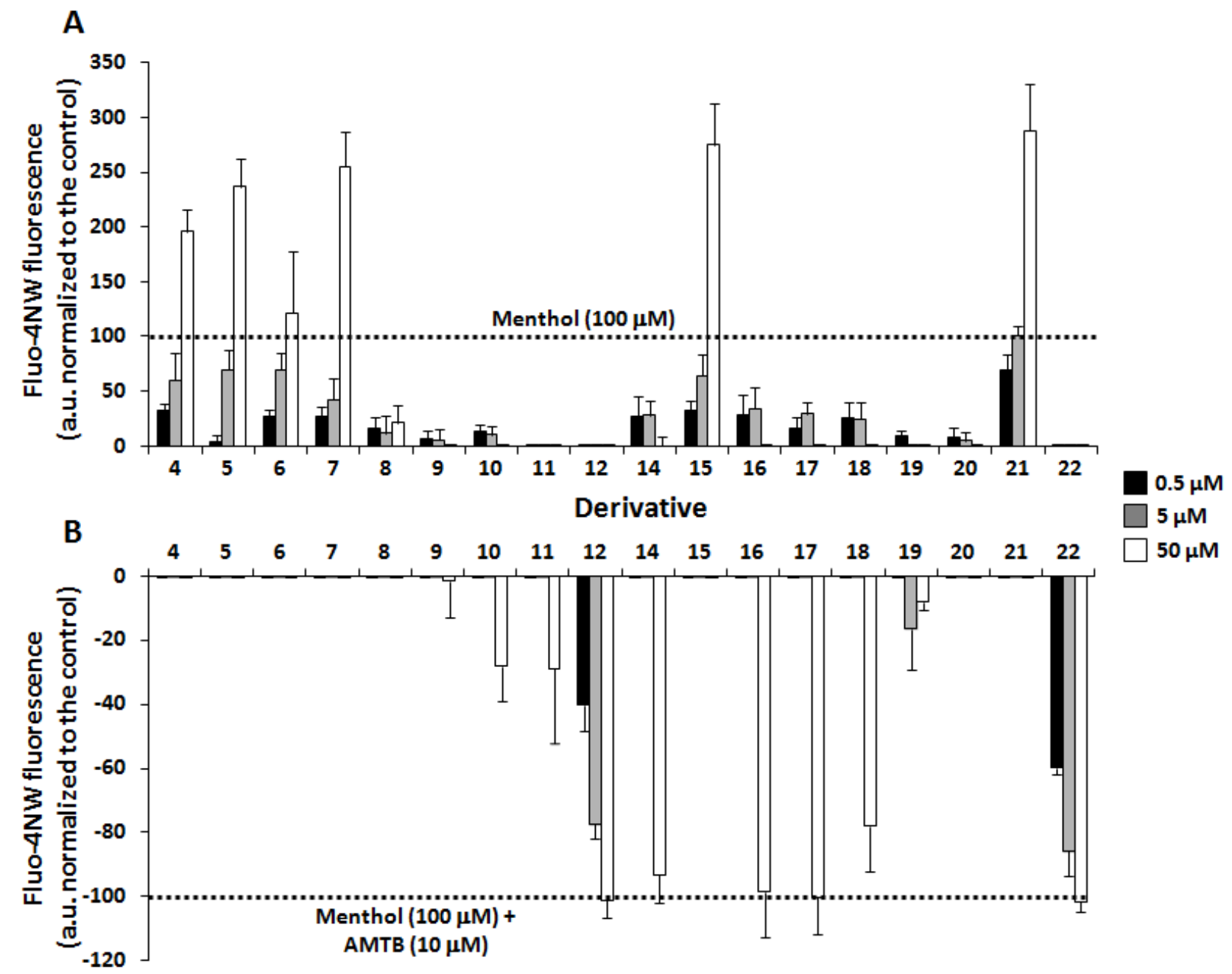

Figure 1: Efficacy of synthesized compounds as TRPM8 agonists (panel A) or antagonists (panel B) at three different increasing concentrations $(0.5 \mu \mathrm{M}, 5 \mu \mathrm{M}$, and $50 \mu \mathrm{M})$. Values are expressed as mean $\pm \mathrm{SEM}$ of 3 independent measurements.

To investigate the ability of newly-described TRPM8 modulators to interfere with the activity of other TRP channels, particularly TRPV1 and TRPA1, two TRPM8 antagonist $(\mathbf{1 2 , 2 2})$ and one agonist (21), were also tested in calcium fluorometric experiments in SH-SY5Y cells stably expressing mouse TRPV1 channels and in IMR90 cells natively expressing mouse TRPA1 channels. In this experiment the canonical TRPV1 agonist (capsaicin, $10 \mu \mathrm{M}$ ) or antagonist (ruthenium red, $10 \mu \mathrm{M}$ ) as well as the canonical TRPA1 agonist (AITC, $500 \mu \mathrm{M}$ ) or antagonist (ruthenium red, $10 \mu \mathrm{M}$ ) were used 
as controls. The values obtained for the tested compounds were normalized to the effects exerted by canonical agonists or agonist + antagonist co-exposure.

As reported in Figure 2, compound 12 appeared a rather selective TRPM8 antagonist, showing weak activity on TRPV1 only at the highest concentration (Figure 2A), and unremarkable activity on TRPA1 at all concentrations (Figure 2B). Interestingly, the TRPM8 agonist 21 behaved instead as an antagonist on both TRPV1 and TRPA1 receptors in study, showing in both, full antagonist ability at the highest concentrations (50 $\mu \mathrm{M}$; Figs. 2A and 2B). Compound 22 appeared less selective, acting as an antagonist of both TRPV1 (Fig. 2A) and TRPA1 (Fig. 2B) channels with potency comparable to that on TRPM8 at all concentrations, and was therefore not further investigated . 


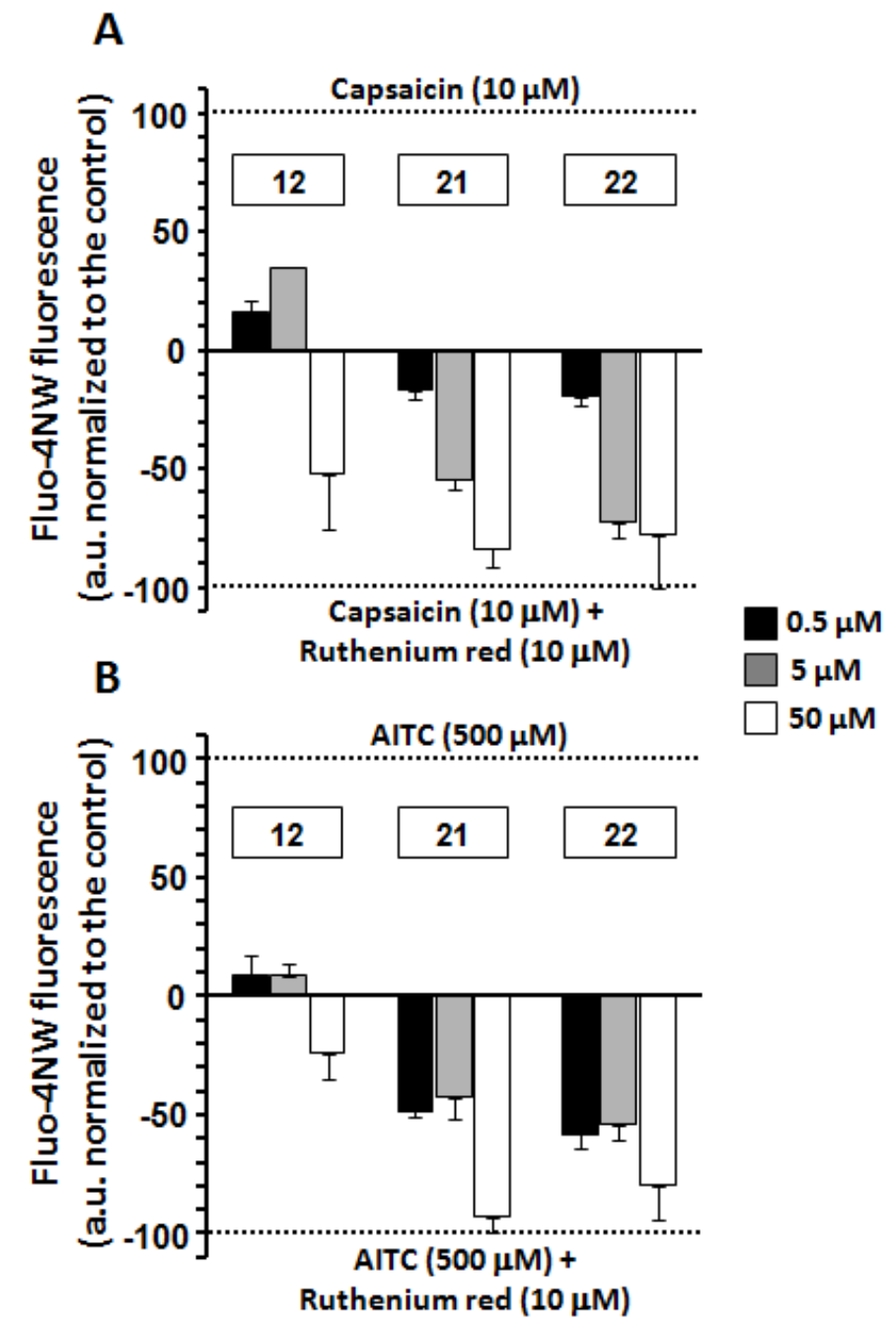

Figure 2: Efficacy of synthesized compounds at three different increasing concentrations $(0.5 \mu \mathrm{M}, 5 \mu \mathrm{M}$ and $50 \mu \mathrm{M})$ as modulators of TRPV1 (vs capsaicin and capsaicin + ruthenium red, panel A) and TRPA1 (vs AITC and AITC + ruthenium red, panel B). Value are expressed as mean \pm SEM of 3 indipendent measurements.

\section{Pharmacological properties of derivatives 21 and 12 characterized by patch-clamp electrophysiology}

The previously described multicellular functional assay identified derivatives $\mathbf{2 1}$ and $\mathbf{1 2}$ as the most effective and potent agonist and antagonist compounds, respectively, on TRPM8 channels. To provide direct evidence for this activity, derivatives $\mathbf{2 1}$ and $\mathbf{1 2}$ were tested in single HEK-293 cells 
transiently expressing the rat TRPM8 isoform by patch-clamp recordings using a 100-msec voltage ramp ranging from $-100 \mathrm{mV}$ to $+100 \mathrm{mV}$ delivered every $4 \mathrm{sec}$. Perfusion with $500 \mu \mathrm{M}$ menthol activated a large, strongly outwardly-rectifying $\left(I_{+80 \mathrm{mv}} / I_{-80 \mathrm{mV}}\right.$ of $\left.90 \pm 25 ; \mathrm{n}=39\right)$ reversing at a potential near $0 \mathrm{mV}(-1.3 \pm 0.7 \mathrm{mV} ; \mathrm{n}=10)$ (Figures 3A and 3B). No currents were activated when menthol was perfused on non-transfected cells $(0 \mathrm{pA} / \mathrm{pF}$ at $+80 \mathrm{mV} ; \mathrm{n}=4$; data not shown $)$. The dose-response curve at $+80 \mathrm{mV}$ of menthol-evoked currents (Figure $3 \mathrm{C}$ ) showed an $\mathrm{EC}_{50}$ of $75 \pm 4 \mu \mathrm{M}$, a value close to those for rat ${ }^{30}$ and mouse isoforms. ${ }^{31,32}$

Perfusion of derivative $21(100 \mu \mathrm{M})$ in rTRPM8-transfected HEK-293 cells also triggered the appearance of large outwardly rectifying currents, reversing around $0 \mathrm{mV}(-1.1 \pm 0.3 \mathrm{mV} ; \mathrm{n}=10$; Figures 3D and 3E). By contrast, perfusion of derivative $12(100 \mu \mathrm{M})$ fails to activate TRPM8 current (data not shown). When compared to menthol, derivative $\mathbf{2 1}$ displayed a significantly higher potency $\left(\mathrm{EC}_{50}\right.$ was $40 \pm 4 \mu \mathrm{M} ; \mathrm{n}=3-10)$ and a similar efficacy $(\mathrm{pA} / \mathrm{pF}$ at $+80 \mathrm{mV}$ were $134 \pm 13$ or $140 \pm 7$ for menthol; $\mathrm{p}>$ 0.05) (Figure 3F). Notably, the presence of the 1-methyl-4-phenoxybenzene group in this derivative (Scheme 2) appears to be crucial for TRPM8 activation, as the derivative $\mathbf{1 1}$ which carries an isoquinoline group showed no agonist activity $(0 \mathrm{pA} / \mathrm{pF}$ at $+80 \mathrm{mV} ; \mathrm{n}=4$; data not shown), as also suggest by fluorescence assay (Figure 1A). 
A
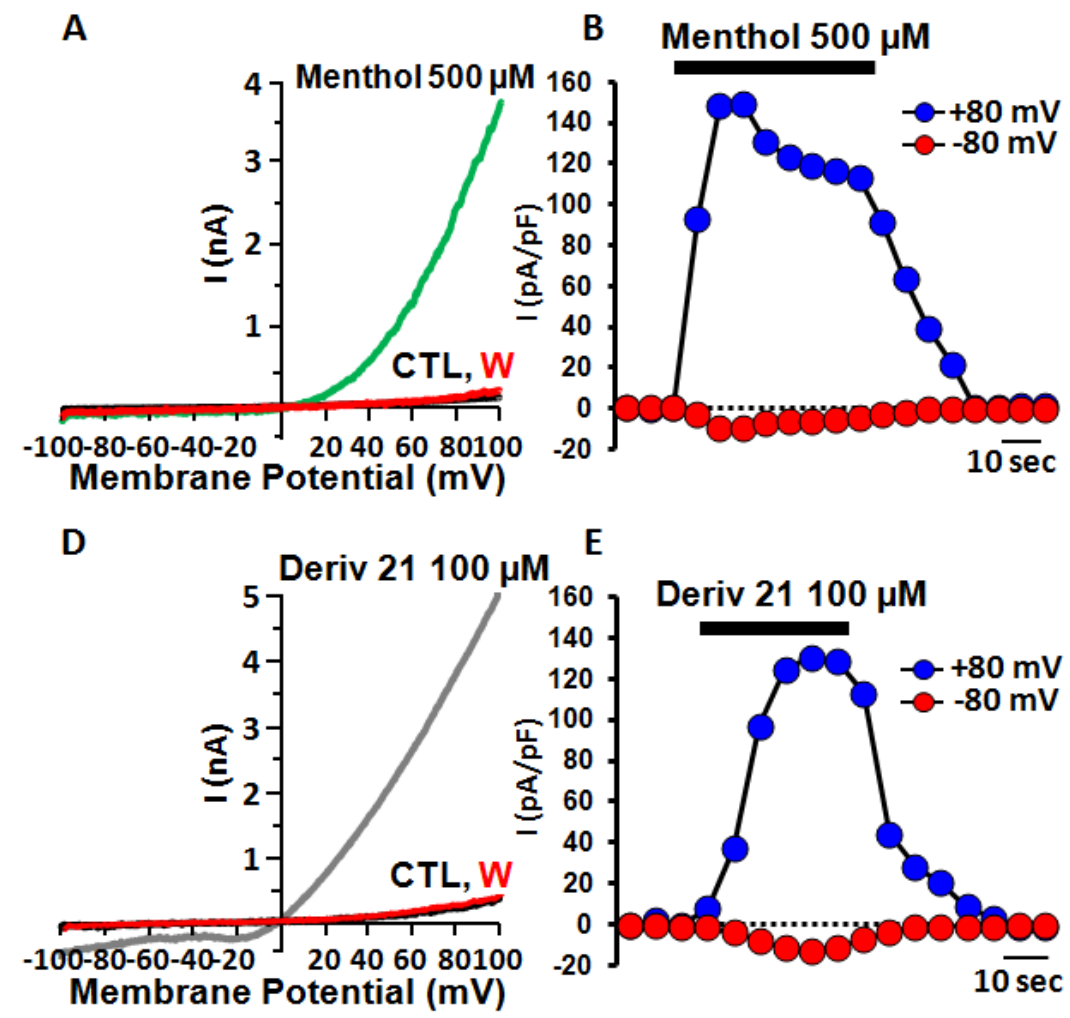

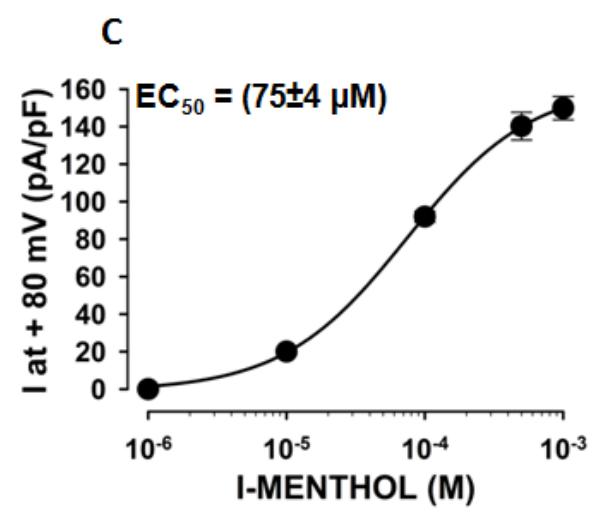

$\mathbf{F}$

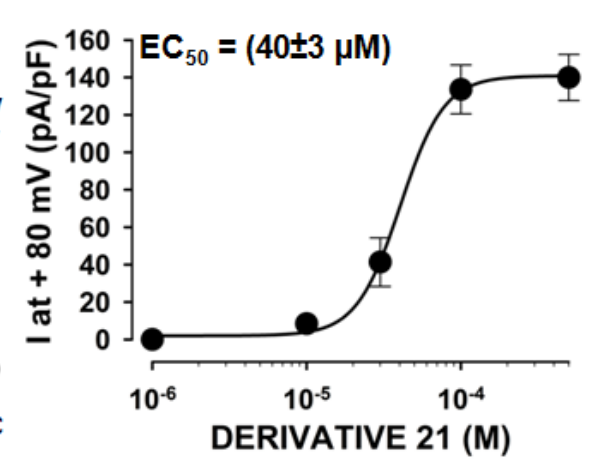

Figure 3: Menthol- and derivative 21-induced currents in HEK293 cells expressing TRPM8. A, D) Representative traces of currents evoked by a $100-\mathrm{ms}$ voltage ramp ranging from $-100 \mathrm{mV}$ to $+100 \mathrm{mV}$ applied every 4 sec, in control solution (CTL; black trace; A,D), during application of menthol (green trace; A) or derivative 12 (gray trace; D) or after washout (W; red trace; A,D). B, E) Time-course of currents recorded at $+80 \mathrm{mV}$ (blue symbols) or $-80 \mathrm{mV}$ (red symbols) in single HEK293 cells expressing TRPM8 upon exposure to menthol $(500 \mu \mathrm{M}$; B) or derivative 12 (100 $\mu \mathrm{M}$; E). The duration of compounds exposure is indicated by the bar on top of the traces. C, F) Concentration-response curves for TRPM8 current activation by menthol $(\mathrm{C})$ or derivative $12(\mathrm{~F})$. Peak current data were expressed as $\mathrm{pA} / \mathrm{pF}$ (to facilitate comparison among cells of different sizes), and expressed as a function of agonist concentrations. The solid lines represent fits of the experimental data to the following binding isotherm: $\mathrm{y}=\max /\left(1+\mathrm{x} / \mathrm{EC}_{50}\right)^{\mathrm{n}}$, where $\mathrm{x}$ is the drug concentration and $\mathrm{n}$ the Hill coefficient. The fitted values for $\mathrm{n}$ were $0.97 \pm 0.05$ or $3.0 \pm 0.6$ for menthol or derivative 12, respectively. Each point is the mean \pm SEM of 4-13 (for menthol) or 3-10 (for derivative 12) determinations, each obtained in different cells.

To investigate possible antagonistic effects exerted by the newly-synthesized compounds, we investigated their ability to inhibit menthol-evoked responses. As previously reported, the canonical TRPM8 antagonist BCTC $(3 \mu \mathrm{M})$ produced a fast and complete inhibition of menthol-gated TRPM8 currents, which largely recovered after drug washout (Figures 4A and 4B). ${ }^{33}$ Similarly, perfusion of the same concentration of derivative 12, produced a complete inhibition of menthol-induced TRPM8 currents measured at $+80 \mathrm{mV}$ (Figures. 4C and 4D), with kinetics slower than that observed for BCTC. 
This block appears concentration-dependent, with an $\mathrm{IC}_{50}$ of $367 \pm 24 \mathrm{nM}(\mathrm{n}=3-9 ;)$, a value slightly lower than that reported for BCTC $(475 \mathrm{nM})^{33}$. These effects were largely reversible upon drug washout (Figure 3C), although with much slower kinetics when compared to those observed for BCTC.
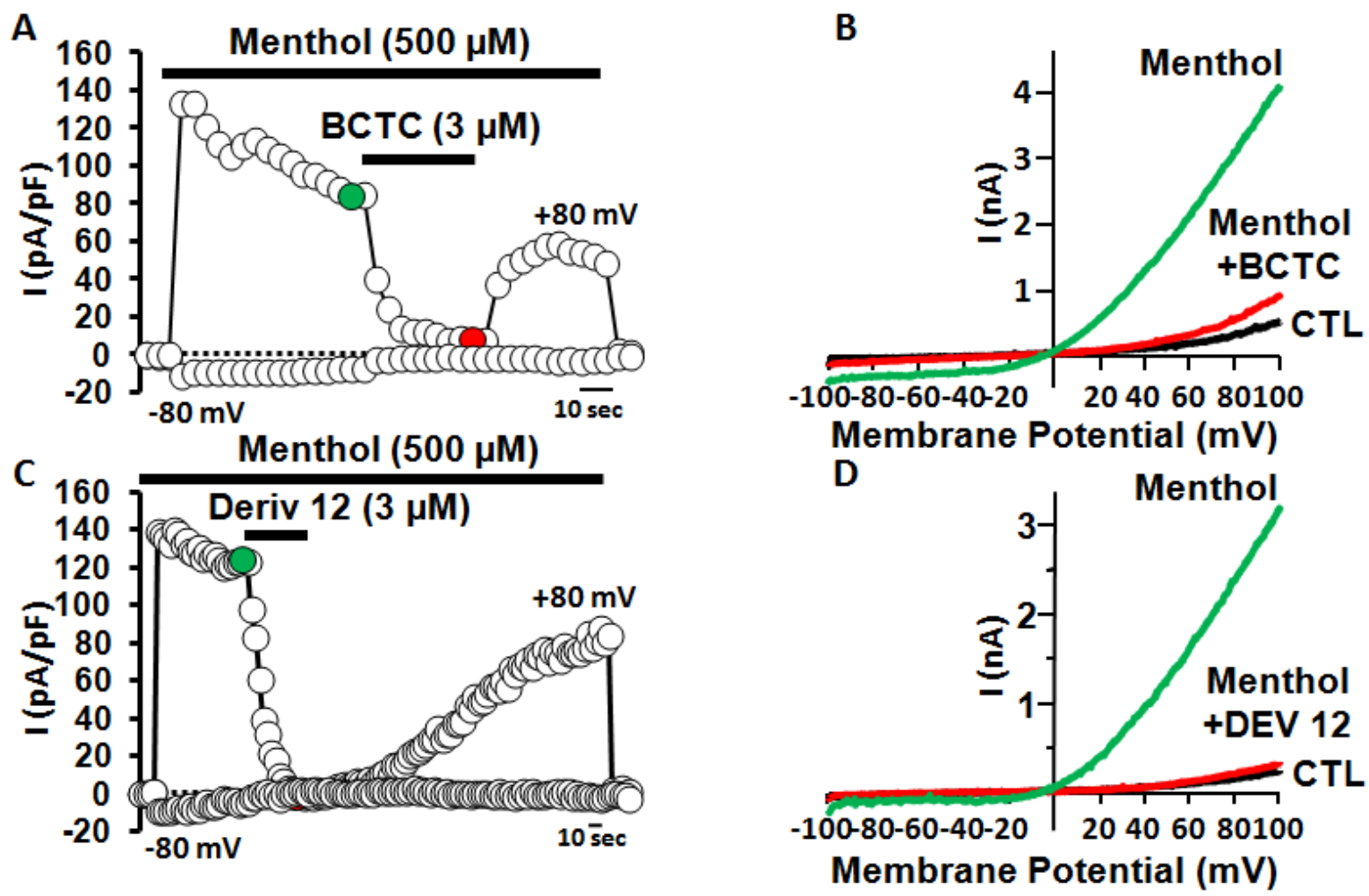

Figure 4: BCTC and derivative 12 block TRPM8-mediated responses evoked by menthol in TRPM8-expressing HEK293 cells. A, C) Time-course of currents recorded at $+80 \mathrm{mV}$ or $-80 \mathrm{mV}$ in HEK293 cells expressing TRPM8 upon application of $500 \mu \mathrm{M}$ menthol (A,C), $500 \mu \mathrm{M}$ menthol $+3 \mu \mathrm{M}$ BCTC (A) or $500 \mu \mathrm{M}$ menthol $+3 \mu \mathrm{M}$ derivative 12 (C). B, D) $I-V$ curves obtained in HEK293 cells expressing TRPM8 and exposed to control solution (CTL; black trace; B,D), $500 \mu \mathrm{M}$ menthol (green trace; B,D), $500 \mu \mathrm{M}$ menthol $+3 \mu \mathrm{M} \mathrm{BCTC}$ (red trace; B) or to $500 \mu \mathrm{M}$ menthol $+3 \mu \mathrm{M}$ derivative 12 (red trace; D). Traces shown in B, D correspond to the currents measured at the time points shown in colors (green or red circles) in $\mathrm{A}, \mathrm{C}$.

\section{Molecular modeling and structural rationale}

In a recent paper, Taberner et al. reported the central role of S6-TRP box linker (amino acids 980-992 in rat TRPM8) in the gating mechanism of TRPM8 channel. ${ }^{34}$ As shown by their homology models based on the experimentally solved structures of TRPV1, the conformational changes in the 
voltage sensors by activating stimuli could be associated to a widening of the S6 C-end, which in turn might disrupts the intersubunit interactions in the region of Tyr981, thus favoring channel opening. ${ }^{35}$

We ran a series of simulations to investigate whether a TRPM8 monomer was able to bind the newly-synthesized small molecules and to test the influence of this binding on the conformation of the functional 980-992 region. We ran SiteMap ${ }^{36}$ calculations on the whole monomer to detect potential binding sites. The best site identified (BP1 - Figure S1), has a volume of $791 \AA$ and a site score of 1.093 (the cutoff value generally used to distinguish between drug-binding and non-drug-binding sites is 0.80 ), and is located between $\mathrm{S} 1, \mathrm{~S} 2, \mathrm{~S} 3$, and $\mathrm{S} 4$ helices, while at the bottom is delimited by residues 990-1010. The proximity of the binding site to the 980-992 region suggests that the binding of a molecule to BP1 might influence the conformation of this linker region in the TRP domain pivotal for coupling stimuli sensing to pore opening. We ran automated molecular docking simulations to predict the binding mode into BP1 of the most potent antagonist (12) and agonist (21) in our series. The bestdocked models were then submitted to 12 ns long molecular dynamics simulations to analyze proteinligand contacts and protein conformational rearrangements at the level of BP1 and of the 980-992 region.

BP1- 12 and BP1- 21 complexes are stabilized by similar interactions, such as hydrophobic contacts with Leu843, Ile701, Leu697, $\pi-\pi$ stacking with Tyr754 and electrostatic interactions with the Glu1004 side chain . A part from these similar interactions, the antagonist and the agonist also show different interactions that could be responsible for different conformational rearrangements of the 980992 region. In particular, 21 makes a hydrogen bond with the phenoxyl group of Tyr754 by its aminolinker and a second hydrogen bond, with the backbone of Arg1008, provided by the indole NH (see figure S2A). The different interaction of $\mathbf{1 2}$ or $\mathbf{2 1}$ to TRPM8 possibly brings to differences in the conformation of BP1, regarding in particular Arg1008. In the closed model of TRPM8 (APO), Arg1008 is projected into BP1, stabilized by hydrogen bonds with Glu1004 and Tyr754 (Figure 5A). 
Upon 21 binding this arginine side chain appears projected outside of BP1 (Figure 5B), with the ligand indole ring claiming its space and hydrogen binding to Arg1008 backbone. Compound 21 makes further hydrogen bonds with the side chain carboxyl of Glu1004, which is shifted away from the position it has in the APO closed model, and with the hydroxyl group of Tyr754. Therefore, the binding of 21 caused an increase in the Arg1008-Glu1004 distance when compared to that measured in the APO TRPM8 configuration (Figure 5D). This conformational rearrangement at the bottom of BP1 prompts an evident shift of the TRP domain helix, that makes the conformation of the 980-992 region looser and prone to rearrange as described below. In the case of $\mathbf{1 2}$ binding, Arg1008 is instead pointing again toward the BP1 cavity, keeping its interaction with Glu1004 as in the APO form (Figures 5C-D).
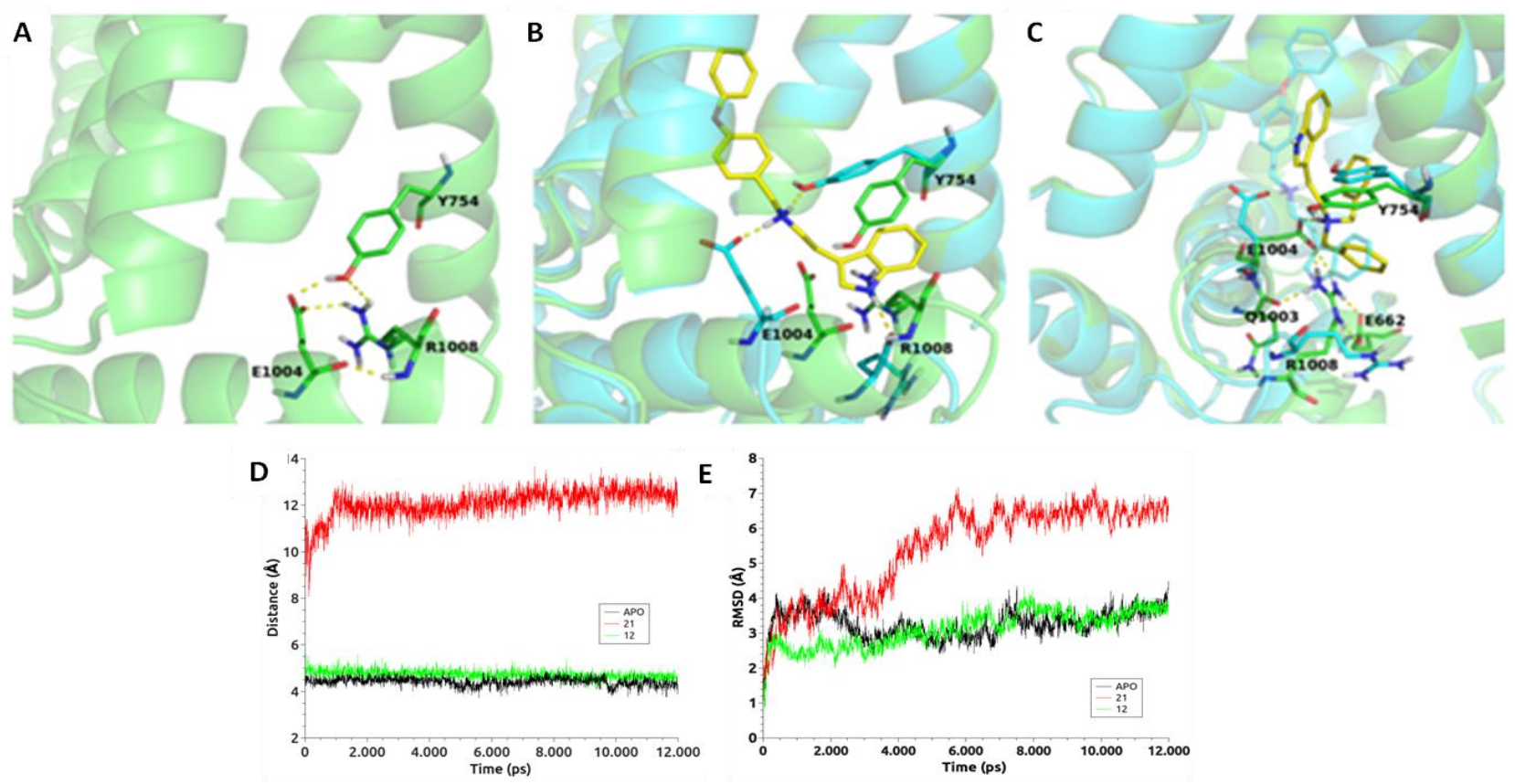

Figure 5: Arg1008 hydrogen bond network (in yellow dashes) in Apo TRPM8 (A) and its changes upon ligand binding: (B) 21 bound conformation of TRPM8 is depicted in cyan, ligand in yellow sticks and apo TRPM8 is depicted in green as reference. (C) 12 bound conformation of TRPM8 is depicted in green, 12 in yellow sticks and 21 bound TRPM8 is depicted in cyan as reference. Arg1008-Glu1004 distances (D) and 980-992 region RMSDs (E) recorded during 12ns long MD trajectories. 
Moreover, this compound establishes a wider hydrogen-bonding network, interacting even with Gln1003 and Glu662, possibly stabilizing the TRP domain helix and causing the antagonism shown by the ligand. Indeed, looking at the RMSD of the 980-992 region as a function of time and of the bound ligand (Figure 5E), it is evident that the conformation of TRPM8/12 is much closer to the APO TRPM8 than TRPM8/21. This behavior indicates that the binding of 21 makes the 980-992 region prone to conformational rearrangement events.

We used the predicted bioactive conformations of $\mathbf{1 2}$ and $\mathbf{2 1}$ to summarize the most stable interactions involved in the binding of these ligands as representative antagonists and agonists of this tryptaminebased series (Figure 6). The pharmacophore model for tryptamine-based agonists accounts for the interaction with Ile837, Leu806, Ile701 (H1), Leu697, Leu843, Ile844 (H2), Glu1004 (D2/P1), Arg1008 (D3), Tyr754 (D1/R1), and Leu757 and Met758 (R1) (Figure 6A).
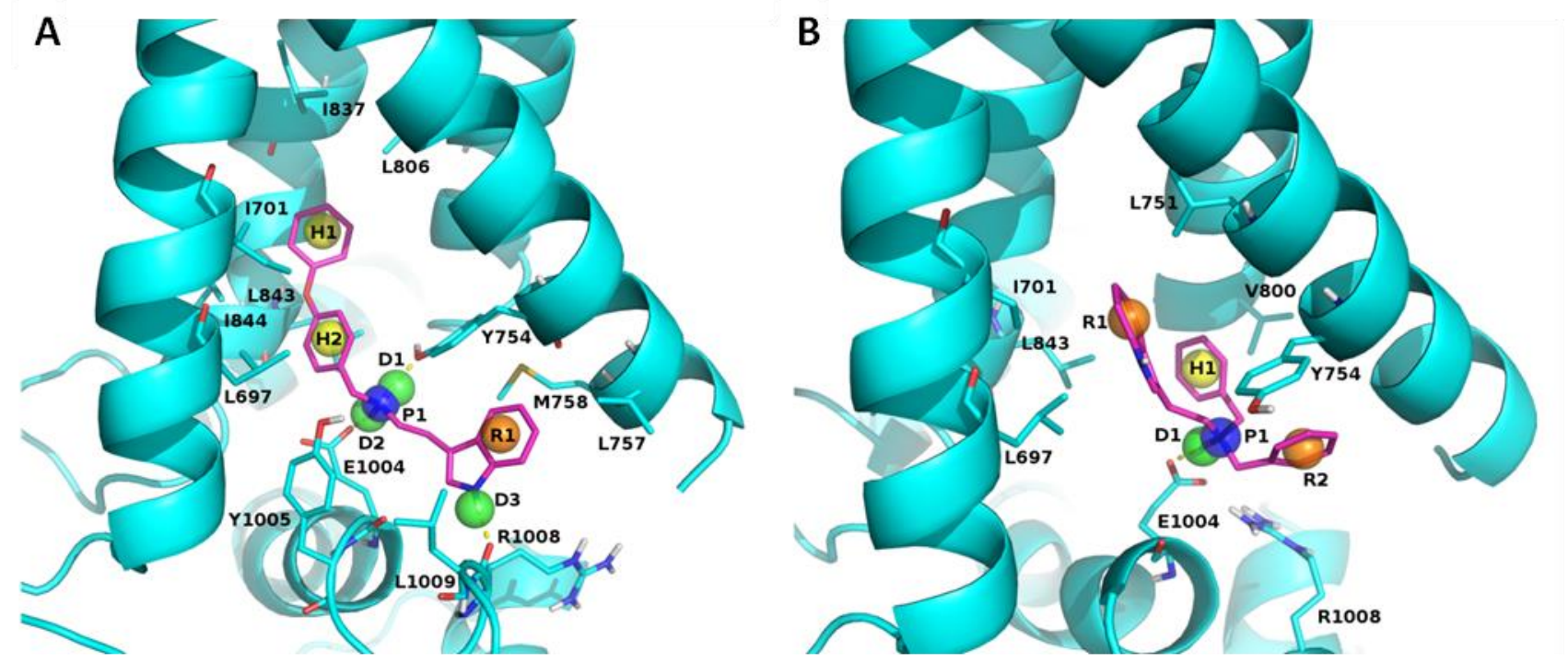

Figure 6. Pharmacophore models for tryptamine-based TRPM8 agonists (A) and antagonists (B). Chemical features are depicted as spheres and color-coded as follows: yellow, $\mathrm{H}=$ hydrophobic, blue, $\mathrm{P}=$ positive charge, green, $\mathrm{D}=\mathrm{HB}$ donor, orange, $\mathrm{R}=$ aromatic ring. $\mathbf{2 1}$ and $\mathbf{1 2}$ are represented as references in panels $\mathrm{A}$ and $\mathrm{B}$, respectively.

On the other hand, the antagonist model accounts for the interaction with Ile701, Leu751, Leu697, Leu843 (R1), Glu1004 (P1/D1), Val800 (H1), Arg1008 (R2) and Tyr754 (R1/R2) (Figure 6B). The two pharmacophore models might help to understand which chemical features are required to endow a 
ligand with agonist or antagonist capabilities. Despite binding to the same site, the two models present in fact substantial differences that may cause the observed differences induced in TRPM8 conformation. All the agonists reported in this paper fit, at least in part, the agonist model. All of them in fact place correctly D1/P1, D2 (compounds 4, 5, 6, 7, 15, and 21) and H1 features (21). R1 location is always occupied by a large substituent claiming the space of Arg 1008 side chain and in same cases this moiety engages in $\mathrm{HB}$ with the Arg1008 backbone. By contrast R2 antagonist feature has to be, when present, a small substituent that does not occupy the Arg1008 room. H1 is probably the feature that boosts the activity of $\mathbf{2 1}$, since it is the only one that perfectly fits it. Regarding the antagonists model, H1, P1 and D1 seem to be the mandatory feature for exerting antagonism (compounds 12 and both conformers of 22 ), while R1 could boost activity by $\pi-\pi$ interaction with Tyr754, and a relatively small R2 substituent could be engaged, by its $\pi$ cloud, in interaction with Tyr754 and the positively charged Arg1008 side chain, improving its antagonist capabilities. Looking at the fittings of the tryptamine-based agonists and antagonists sets, it seems that the mandatory features to exert agonism are $\mathrm{H} 2, \mathrm{P} 1, \mathrm{D} 1$ and $\mathrm{D} 2$, while on the other side $\mathrm{H} 1, \mathrm{P} 1$ and $\mathrm{D} 1$ are necessary for the antagonists (see Table S1).

\section{Conclusions}

Here we report the synthesis and pharmacological evaluation of a small library based on the tryptamine scaffold designed as TRPM8 ion channel modulators. Two of the synthesized derivatives, compounds 12 and 21, showed to be efficient and potent TRPM8 antagonist and agonist, respectively. In fact, 12 produced a complete inhibition of menthol-induced TRPM8 currents with a higher potency than that reported for the well-known TRPM8 antagonist BCTC. Meanwhile the agonist 21 showed a significantly higher potency and efficacy than menthol. In addition, compound 12 showed 
unremarkable activity on TRPV1 and TRPA1 at different concentrations while the agonist 21 behaved as an antagonist on both TRPV1 and TRPA1 receptors at high concentration.

Computational studies allowed us to hypothesize a binding site and two pharmacophore prototypes for this series of tryptamine-based TRPM8 modulators. The proposed structural model identifies the same binding site for agonist and antagonist, but two binding modes differing in the "interaction network". Since structural models have to be used with caution, further investigations are needed to confirm the structural hypothesis. The results of this study provide valuable information for the future design of new and specific TRPM8 modulators that could be useful in the treatment of different diseases involving a deregulation of this ion channel.

\section{Experimental section}

General. Reagents, starting materials, and solvents were purchased from Sigma-Aldrich (Milan, Italy) and used as received. Reactions were carried out with magnetic stirring in round-bottomed flasks unless otherwise noted. Moisture-sensitive reactions were conducted in oven-dried glassware under a positive pressure of dry nitrogen, using pre-dried, freshly distilled solvents. Microwave assisted reactions were performed in a Biotage Initiator $^{+}$reactor. Analytical thin layer chromatography (TLC) was performed on pre-coated glass silica gel plates 60 (F254, $0.25 \mathrm{~mm}$, VWR International). Purifications were performed by flash column chromatography on silica gel (230-400 mesh, Merck Millipore). NMR spectra were recorded on Varian Mercury-400 apparatus. ${ }^{1} \mathrm{HNMR}$ and ${ }^{13} \mathrm{C}$ NMR spectra were recorded with a Varian-400 spectrometer, operating at 400 and $100 \mathrm{MHz}$, respectively. Chemical shifts are reported in $\delta$ values (ppm) relative to internal $\mathrm{Me}_{4} \mathrm{Si}$, and $\mathrm{J}$ values are reported in hertz $(\mathrm{Hz})$. The following abbreviations are used to describe peaks: s (singlet), d (doublet), dd (double double), $\mathrm{t}$ (triplet), q (quadruplet) and $\mathrm{m}$ (multiplet). ESI-MS experiments were performed on an Applied Biosystem API 2000 triple-quadrupole spectrometer. Combustion microanalyses were 
performed on a Carlo Erba CNH 1106 analyzer, and were within $0.4 \%$ of calculated values and confirmed $>95 \%$ purity for the final products. Analytical RP-HPLC was performed on a Phenomenex Synergi Fusion RP-80A (75 x $4.6 \mathrm{~mm}, 4 \mu \mathrm{M})$, with a flow rate of $1 \mathrm{ml} / \mathrm{min}$, using a tunable UV detector at $254 \mathrm{~nm}$. Mixtures of $\mathrm{CH}_{3} \mathrm{CN}$ and $0.05 \%$ TFA in $\mathrm{H}_{2} \mathrm{O}$ were used as mobile phase.

\section{General procedure for the synthesis of derivatives 2 and 3.}

3-(2-Bromoethyl)indole (1, 1.0 eq) was dissolved in a mixture of anhydrous DCM/DMF (2/1 v/v) under magnetic stirring and the temperature was set to $0^{\circ} \mathrm{C}$. To this solution, 1.5 equivalents of $\mathrm{NaH}$ were added portionwise and the mixture was allowed to react for 30 minutes. Then, 1.5 equivalents of alkyl iodide [methyl iodide or 4-[phenyl]iodomethylbenzene (III)] in DCM were added dropwise and the reaction was warmed to room temperature and maintained under stirring for further $12 \mathrm{~h}$. Then, reaction was quenched by $10 \%$ aqueous solution of citric acid and washed with brine. Organic layer was separated, dried over anhydrous $\mathrm{Na}_{2} \mathrm{SO}_{4}$, filtered and evaporated in vacuo. Crude products were purified by column chromatography using n-hexane/ethyl acetate (4:1 v:v) as mobile phase.

\section{3-(2-Bromoethyl)-1-methyl-1H-indole (2).}

Yield 67\%. ${ }^{1} \mathrm{H}$ NMR $\left(400 \mathrm{MHz}_{\mathrm{CDCl}}\right) \delta 3.39-3.46\left(\mathrm{~m}, 4 \mathrm{H}, \mathrm{CH}_{2}\right) ; 3.79\left(\mathrm{~s}, 3 \mathrm{H}, \mathrm{CH}_{3}\right) ; 6.97(\mathrm{~s}, 1 \mathrm{H})$; $7.20(\mathrm{t}, 1 \mathrm{H}, J=7.6 \mathrm{~Hz}) ; 7.28(\mathrm{~d}, 1 \mathrm{H}, J=8.0 \mathrm{~Hz}) ; 7.34(\mathrm{t}, 1 \mathrm{H}, J=8.0 \mathrm{~Hz}) ; 7.62(\mathrm{~d}, 1 \mathrm{H}, J=8.0 \mathrm{~Hz})$. ESIMS m/z calcd for $\mathrm{C}_{11} \mathrm{H}_{12} \mathrm{BrN}, 237.02$; found $238.11\left(\mathrm{M}+\mathrm{H}^{+}\right)$

\section{Synthesis of 1-(Iodomethyl)-4-phenylbenzene intermediate (III).}

To one equivalent of biphenyl-4-carboxylic acid (I) dissolved in dry THF was added portionwise $\mathrm{LiAlH}_{4}(3.0 \mathrm{eq})$, under stirring at room temperature (Scheme 2). After 2 hours the solution was washed three times with $\mathrm{HCl} 2 \mathrm{~N}$ and then water and the organic layer was dried over anhydrous $\mathrm{Na}_{2} \mathrm{SO}_{4}$, filtered and concentrated. The resultant 4-biphenylmethanol (II) was purified by flash chromatography 
using ethyl acetate as solvent and was obtained as oil in $89 \%$ yield. ${ }^{1} \mathrm{H} \mathrm{NMR}\left(400 \mathrm{MHz}, \mathrm{CDCl}_{3}\right) \delta 2.98$ (bs, 1H, OH); $4.70\left(\mathrm{~s}, 2 \mathrm{H}, \mathrm{CH}_{2}\right) ; 7.33-7.43$ (m, 5H, aryl); 7.59-7.61 (m, 4H, Aryl).

Then, treatment of II with triphenylphosphine and $\mathrm{I}_{2}$, in dry DCM, according to the procedure

previously described, ${ }^{27}$ gave the title compound in $65 \%$ yield. ${ }^{1} \mathrm{H}$ NMR $\left(400 \mathrm{MHz}, \mathrm{CDCl}_{3}\right) \delta 4.53(\mathrm{~s}$, $\left.2 \mathrm{H}, \mathrm{CH}_{2}\right) ; 7.15(\mathrm{~d}, 2 \mathrm{H}, J=8.0 \mathrm{~Hz}) ; 7.24(\mathrm{~d}, 2 \mathrm{H}, J=8.0 \mathrm{~Hz}) ; 7.43-7.55(\mathrm{~m}, 5 \mathrm{H})$.

\section{1-(Biphenyl-4-ylmethyl)-3-(2-bromoethyl)-1H-indole (3).}

Prepared from intermediate III and 3-(2-bromoethyl)indole as described above. Yield 61\%. ${ }^{1} \mathrm{H}$ NMR $\left(400 \mathrm{MHz}, \mathrm{CD}_{3} \mathrm{OD}\right) \delta 3.27\left(\mathrm{t}, 1 \mathrm{H}, J=7.4 \mathrm{~Hz}, \mathrm{CH}_{2}\right) ; 3.38-3.46\left(\mathrm{~m}, 2 \mathrm{H}, \mathrm{CH}_{2}\right) ; 3.81(\mathrm{t}, 1 \mathrm{H}, J=7.6 \mathrm{~Hz}$, $\left.\mathrm{CH}_{2}\right) ; 5.35\left(\mathrm{~s}, 2 \mathrm{H}, \mathrm{CH}_{2}\right) ; 7.07(\mathrm{~s}, 1 \mathrm{H}) ; 7.14-7.61(\mathrm{~m}, 13 \mathrm{H})$. ESIMS m/z calcd for $\mathrm{C}_{23} \mathrm{H}_{20} \mathrm{BrN}, 391.08$; found $392.13\left(\mathrm{M}+\mathrm{H}^{+}\right)$.

\section{General procedure for the synthesis of derivatives 4-12.}

One equivalent of 3-(2-bromoethyl)indole (1) or intermediate $\mathbf{2}$ or $\mathbf{3}$ was dissolved in THF and 1.5 eq of the proper amine, 1.5 eq of TEA, 1.5 eq of $\mathrm{NaI}$ and 0.3 eq of $\left(\mathrm{CH}_{3} \mathrm{COO}\right)_{2} \mathrm{Pd}$ were added to this solution (Scheme I). The reaction was conducted under $\mu \mathrm{W}$, at $100^{\circ} \mathrm{C}$, for 20 minutes. The resulting mixture was filtered through Celite, dried in vacuo and reconstituted in DCM. The organic phase was washed with water $(3 \times 50 \mathrm{~mL})$, dried over anhydrous $\mathrm{Na}_{2} \mathrm{SO}_{4}$, filtered, concentrated and purified by column chromatography using $\mathrm{DCM} / \mathrm{MeOH}$ as mobile phase.

\section{N-(4-Methoxybenzyl)-2-(1-methyl-1H-indol-3-yl)ethanamine (4)}

Synthesized starting from 3 and 4-methoxybenzylamine, yield 71\%. ${ }^{1} \mathrm{H}$ NMR $\left(400 \mathrm{MHz}, \mathrm{CDCl}_{3}\right) \delta 2.92$ $\left(\mathrm{t}, 2 \mathrm{H}, J=7.6 \mathrm{~Hz}, \mathrm{CH}_{2}\right) ; 3.19\left(\mathrm{t}, 2 \mathrm{H}, J=7.6 \mathrm{~Hz}, \mathrm{CH}_{2}\right) ; 3.49\left(\mathrm{~s}, 6 \mathrm{H}, 2 \mathrm{CH}_{3}\right) ; 3.72\left(\mathrm{~s}, 2 \mathrm{H}, \mathrm{CH}_{2}\right) ; 6.81(\mathrm{~s}$, $1 \mathrm{H}) ; 7.07-7.15(\mathrm{~m}, 3 \mathrm{H}) ; 7.20(\mathrm{t}, 1 \mathrm{H}, J=6.8 \mathrm{~Hz}) ; 7.24-7.30(\mathrm{~m}, 3 \mathrm{H}) ; 7.52(\mathrm{~d}, 1 \mathrm{H}, J=8.0 \mathrm{~Hz}) .{ }^{13} \mathrm{C} \mathrm{NMR}$ $\left(100 \mathrm{MHz}, \mathrm{CDCl}_{3}\right) \delta 22.7,41.6,50.8,57.1,109.1,110.0,112.4,118.6,118.8,121.4,121.9,124.2$, 126.4, 128.0, 128.3, 135.3, 199.8. ESIMS m/z calcd for $\mathrm{C}_{19} \mathrm{H}_{22} \mathrm{~N}_{2} \mathrm{O}, 294.17$; found 295.20 $\left(\mathrm{M}+\mathrm{H}^{+}\right)$. 
Synthesized starting from 3 and 4-chlorobenzylamine, yield 69\%. ${ }^{1} \mathrm{H}$ NMR $\left(400 \mathrm{MHz}, \mathrm{CDCl}_{3}\right) \delta 2.93-$ $3.00\left(\mathrm{~m}, 4 \mathrm{H}, 2 \mathrm{CH}_{2}\right) ; 3.74\left(\mathrm{~s}, 3 \mathrm{H}, \mathrm{CH}_{3}\right) ; 3.77\left(\mathrm{~s}, 2 \mathrm{H}, \mathrm{CH}_{2}\right) ; 6.87(\mathrm{~s}, 1 \mathrm{H}) ; 7.10(\mathrm{t}, 1 \mathrm{H}, J=8.0 \mathrm{~Hz}) ; 7.20-$

$7.30(\mathrm{~m}, 6 \mathrm{H}) ; 7.58(\mathrm{~d}, 1 \mathrm{H}, J=8.0 \mathrm{~Hz}) .{ }^{13} \mathrm{C} \mathrm{NMR}\left(100 \mathrm{MHz}, \mathrm{CDCl}_{3}\right) \delta 25.57,32.56,49.40,53.06$, 109.2, 110.0, 112.3, 118.7, 118.9, 121.6, 126.7, 127.8, 128.4, 129.4, 132.5, 137.1, 138.7. ESIMS m/z calcd for $\mathrm{C}_{18} \mathrm{H}_{19} \mathrm{ClN}_{2}, 298.12$; found $299.17\left(\mathrm{M}+\mathrm{H}^{+}\right)$.

\section{2-([1,1'-Biphenyl]-4-yl)-N-(2-(1-methyl-1H-indol-3-yl)ethyl)ethanamine (6).}

Synthesized starting from 3 and 2-(4-biphenyl)ethylamine, yield 65\%. ${ }^{1} \mathrm{H}$ NMR (400 MHz,CD $\left.{ }_{3} \mathrm{OD}\right) \delta$ $3.03\left(\mathrm{t}, 2 \mathrm{H}, J=8.8 \mathrm{~Hz}, \mathrm{CH}_{2}\right) ; 3.17\left(\mathrm{t}, 2 \mathrm{H}, J=8.6 \mathrm{~Hz}, \mathrm{CH}_{2}\right) ; 3.32-3.37\left(\mathrm{~m}, 4 \mathrm{H}, \mathrm{CH}_{2}\right) ; 3.76\left(\mathrm{~s}, 3 \mathrm{H}, \mathrm{CH}_{3}\right)$; 7.06-7.11 (m, 2H); $7.20(\mathrm{t}, 1 \mathrm{H}, J=7.2 \mathrm{~Hz}) ; 7.31-7.44(\mathrm{~m}, 6 \mathrm{H}) ; 7.56-7.60(\mathrm{~m}, 5 \mathrm{H}) .{ }^{13} \mathrm{C}$ NMR $(100$ $\left.\mathrm{MHz}, \mathrm{CD}_{3} \mathrm{OD}\right) \delta 22.0,31.7,48.4,109.4,118.0,119.0,121.8,126.7,127.3,127.5,128.7,129.1,135.5$. ESIMS m/z calcd for $\mathrm{C}_{25} \mathrm{H}_{26} \mathrm{~N}_{2}, 354.21$; found $355.26\left(\mathrm{M}+\mathrm{H}^{+}\right)$.

2-(1-([1,1'-Biphenyl]-4-ylmethyl)-1H-indol-3-yl)-N-(3,4-dimethoxyphenethyl)ethanamine

Synthesized starting from $\mathbf{3}$ and 3,4-dimethoxyphenthylamine, yield $75 \%$. ${ }^{1} \mathrm{H}$ NMR (400 $\left.\mathrm{MHz}, \mathrm{CD}_{3} \mathrm{OD}\right) \delta 2.91\left(\mathrm{t}, 2 \mathrm{H}, J=7.2 \mathrm{~Hz}, \mathrm{CH}_{2}\right) ; 3.17-3.26\left(\mathrm{~m}, 4 \mathrm{H}, \mathrm{CH}_{2}\right) ; 3.34\left(\mathrm{t}, 2 \mathrm{H}, J=7.4 \mathrm{~Hz}, \mathrm{CH}_{2}\right)$; $3.77\left(\mathrm{~s}, 3 \mathrm{H}, \mathrm{OCH}_{3}\right) ; 3.79\left(\mathrm{~s}, 3 \mathrm{H}, \mathrm{OCH}_{3}\right) ; 5.39\left(\mathrm{~s}, 2 \mathrm{H}, \mathrm{CH}_{2}\right) ; 6.83-6.87(\mathrm{~m}, 2 \mathrm{H}) ; 7.09(\mathrm{t}, 1 \mathrm{H}, J=8.0 \mathrm{~Hz})$; 7.11-7.24 (m, 5H); 7.37-7.41 (m, 4H); 7.50-7.55 (m, 4H); $7.62(\mathrm{~d}, 1 \mathrm{H}, J=8.0 \mathrm{~Hz}) .{ }^{13} \mathrm{C}$ NMR $(100$ $\left.\mathrm{MHz}, \mathrm{CD}_{3} \mathrm{OD}\right) \delta 22.1,31.7,48.8,49.2,55.2,109.2,110.1,112.1,112.3,118.3,119.3,120.9,112.0$, 126.7, 126.9, 127.0, 127.2, 127.4, 127.7, 128.7, 129.0, 137.3, 140.7, 148.6 149.6. ESIMS m/z calcd for $\mathrm{C}_{33} \mathrm{H}_{34} \mathrm{~N}_{2} \mathrm{O}_{2}$, 490.26; found $491.31\left(\mathrm{M}+\mathrm{H}^{+}\right)$.

\section{N-[2-(1H-Indol-3-yl)ethyl]naphthalen-1-amine (8).}

Synthesized starting from 1 and 1-naphtalenlamine, yield 55\%. ${ }^{1} \mathrm{H}$ NMR $\left(400 \mathrm{MHz}, \mathrm{CDCl}_{3}\right) \delta 3.26(\mathrm{t}$, $\left.2 \mathrm{H}, J=8.0 \mathrm{~Hz}, \mathrm{CH}_{2}\right) ; 3.64\left(\mathrm{t}, 2 \mathrm{H}, J=8.2 \mathrm{~Hz}, \mathrm{CH}_{2}\right) ; 6.70(\mathrm{~d}, 1 \mathrm{H}, J=7.8 \mathrm{~Hz}) ; 7.06(\mathrm{~s}, 1 \mathrm{H}) ; 7.20(\mathrm{t}, 1 \mathrm{H}$, $J=7.2 \mathrm{~Hz}) ; 7.25-7.27(\mathrm{~m}, 2 \mathrm{H}) ; 7.37-7.43(\mathrm{~m}, 4 \mathrm{H}) ; 7.66(\mathrm{~d}, 1 \mathrm{H}, J=7.6 \mathrm{~Hz}) ; 7.72(\mathrm{~d}, 1 \mathrm{H}, J=8.0 \mathrm{~Hz}) ; 7.80$ $(\mathrm{d}, 1 \mathrm{H}, J=8.2 \mathrm{~Hz}) ; 7.98(\mathrm{~s}, 1 \mathrm{H}, \mathrm{NH}) .{ }^{13} \mathrm{C} \mathrm{NMR}\left(100 \mathrm{MHz}, \mathrm{CDCl}_{3}\right) \delta 25.1 ; 44.3 ; 104.7,111.5 ; 113.6$; 
$117.5,119.0,119.8,120.1,122.3 ; 122.5 ; 123.7 ; 124.8,125.9,126.9 ; 127.6 ; 128.9 ; 133.4 ; 136.7,143.7$. ESI-MS m/z calcd for $\mathrm{C}_{20} \mathrm{H}_{18} \mathrm{~N}_{2}, 286.15$; found $287.20\left(\mathrm{M}+\mathrm{H}^{+}\right)$.

N-[2-(1H-Indol-3-yl)ethyl]naphthalen-2-amine (9).

Synthesized starting from 1 and 2-naphtalenlamine, yield 58\%. ${ }^{1} \mathrm{H}$ NMR $\left(400 \mathrm{MHz}, \mathrm{CDCl}_{3}\right) \delta 3.16(\mathrm{t}$, $\left.2 \mathrm{H}, J=7.8 \mathrm{~Hz} \mathrm{CH} \mathrm{CH}_{2}\right) ; .58\left(\mathrm{t}, 2 \mathrm{H}, J=8.0 \mathrm{~Hz}, \mathrm{CH}_{2}\right) ; 6.81-6.85(\mathrm{~m}, 2 \mathrm{H}) ; 7.08(\mathrm{~s}, 1 \mathrm{H}) ; 7.12-7.24(\mathrm{~m}, 4 \mathrm{H})$; 7.33-7.40 (m, 3H); 7.59 (d, 1H, J=8.4 Hz); $7.64(\mathrm{~d}, 1 \mathrm{H}, J=8.2 \mathrm{~Hz}) ; 8.07(\mathrm{~s}, 1 \mathrm{H}, \mathrm{NH}) .{ }^{13} \mathrm{C}$ NMR $(100$ $\left.\mathrm{MHz}, \mathrm{CDCl}_{3}\right) \delta 25.1 ; 44.1 ; 104.8,111.4,118.4,119.0,119.7$ 122.1, 122.3; 122.4; 123.0; 126.1; 126.5; $126.8 ; 127.4 ; 127.8 ; 129.1 ; 133.7 ; 136.5 ; 146.0$. ESI-MS m/z calcd for $\mathrm{C}_{20} \mathrm{H}_{18} \mathrm{~N}_{2}, 286.15$; found 287.17 $\left(\mathrm{M}+\mathrm{H}^{+}\right)$.

\section{2-(1H-Indol-3-yl)-N-(quinolin-5-yl-methyl)ethanamine (10).}

Synthesized starting from 1 and 5-aminoquinoline, yield 63\%. ${ }^{1} \mathrm{H}$ NMR $\left(400 \mathrm{MHz}, \mathrm{CDCl}_{3}\right) \delta 3.26(\mathrm{t}$, $\left.2 \mathrm{H}, J=8.0 \mathrm{~Hz}, \mathrm{CH}_{2}\right) ; 3.62\left(\mathrm{t}, 2 \mathrm{H}, J=8.2 \mathrm{~Hz}, \mathrm{CH}_{2}\right) ; 6.82(\mathrm{~d}, 1 \mathrm{H}, J=7.6 \mathrm{~Hz}) ; 7.12-7.48(\mathrm{~m}, 7 \mathrm{H}) ; 7.69(\mathrm{~d}$, $1 \mathrm{H}, J=7.8 \mathrm{~Hz}) ; 8.15(\mathrm{~s}, 1 \mathrm{H}, \mathrm{NH}) ; 8.37(\mathrm{~d}, 1 \mathrm{H}, J=4.0 \mathrm{~Hz}) ; 9.13(\mathrm{~d}, 1 \mathrm{H}, J=4.0 \mathrm{~Hz}) .{ }^{13} \mathrm{C}$ NMR $(100 \mathrm{MHz}$, $\left.\mathrm{CDCl}_{3}\right) \delta 24.9 ; 44.1 ; 107.9 ; 111.6 ; 113.0 ; 113.6,116.2 ; 118.9 ; 119.4 ; 119.8,122.3 ; 122.6 ; 127.4 ; 128.4 ;$ 136.5; 138.7; 141.9; 146.6, 153.0. ESI-MS m/z calcd for $\mathrm{C}_{19} \mathrm{H}_{17} \mathrm{~N}_{3}, 287.14$; found $288.26\left(\mathrm{M}+\mathrm{H}^{+}\right)$.

\section{2-(1H-Indol-3-yl)-N-(isoquinolin-5-ylmethyl)ethanamine (11).}

Synthesized starting from 1 and 5-aminoisoquinoline, yield 67\%. ${ }^{1} \mathrm{H}$ NMR $\left(400 \mathrm{MHz}, \mathrm{CDCl}_{3}\right) \delta 3.23$ (t, $\left.2 \mathrm{H}, J=6.4 \mathrm{~Hz}, \mathrm{CH}_{2}\right) ; 3.61\left(\mathrm{t}, 2 \mathrm{H}, J=6.2 \mathrm{~Hz}, \mathrm{CH}_{2}\right) ; 7.82(\mathrm{~d}, 1 \mathrm{H}, J=8.0 \mathrm{~Hz}) ; 7.15-7.54(\mathrm{~m}, 7 \mathrm{H}) ; 7.71$ $(\mathrm{d}, 1 \mathrm{H}, J=8.0 \mathrm{~Hz}) ; 8.11(\mathrm{~s}, 1 \mathrm{H}, \mathrm{NH}) ; 8.39(\mathrm{~d}, 1 \mathrm{H}, J=7.2 \mathrm{~Hz}) ; 9.17(\mathrm{~s}, 1 \mathrm{H}) .{ }^{13} \mathrm{C} \mathrm{NMR}\left(100 \mathrm{MHz}, \mathrm{CDCl}_{3}\right)$ $\delta 25.9 ; 49.9 ; 111.4 ; 114.9 ; 116.9,119.0,119.5,122.3,122.4,127.0 ; 127.3 ; 127.5 ; 127.7 ; 130.1 ; 134.7$; 134.9; 135.4; 136.6; 143.3; 153.2. ESIMS m/z calcd for $\mathrm{C}_{19} \mathrm{H}_{17} \mathrm{~N}_{3}$ 287.14; found $288.24\left(\mathrm{M}+\mathrm{H}^{+}\right)$.

\section{N,N-Dibenzyl-2-(1H-indol-3-yl)ethanamine (12).}

Synthesized starting from 1 and dibenzylamine, yield $73 \% .{ }^{1} \mathrm{H}$ NMR $\left(400 \mathrm{MHz}, \mathrm{CDCl}_{3}\right) \delta 2.84(\mathrm{t}, 2 \mathrm{H}$, $\left.J=5.6 \mathrm{~Hz}, \mathrm{CH}_{2}\right) ; 3.01\left(\mathrm{t}, 2 \mathrm{H}, J=6.0 \mathrm{~Hz}, \mathrm{CH}_{2}\right) ; 3.73\left(\mathrm{~s}, 4 \mathrm{H}, 2 \mathrm{CH}_{2}\right) ; 6.90(\mathrm{~s}, 1 \mathrm{H}) ; 7.06(\mathrm{t}, 1 \mathrm{H}, J=8.2$ 
$\mathrm{Hz}$, aryl); $7.18(\mathrm{t}, 1 \mathrm{H}, J=8.0 \mathrm{~Hz}) ; 7.26(\mathrm{t}, 2 \mathrm{H}, J=8.4 \mathrm{~Hz}) ; 7.32-7.35(\mathrm{~m}, 5 \mathrm{H}) ; 7.40-7.43(\mathrm{~m}, 5 \mathrm{H}) ; 7.85$

$(\mathrm{s}, 1 \mathrm{H}, \mathrm{N} H) .{ }^{13} \mathrm{C}$ NMR $\left(100 \mathrm{MHz}, \mathrm{CDCl}_{3}\right) \delta 23.3 ; 54.1 ; 58.5 ; 111.2 ; 114.8 ; 119.1,119.3,121.6,122.0$ 127.0; 127.8; 128.4; 129.0; 136.4; 140.1. ESI-MS m/z calcd for $\mathrm{C}_{24} \mathrm{H}_{24} \mathrm{~N}_{2}, 340.19$ found 341.27 $\left(\mathrm{M}+\mathrm{H}^{+}\right)$.

Synthesis of N-[(1,2,3,4,Tetrahydronaphthalen-1-yl)methyl]-2-(1H-indol-3-yl)ethanamine (14). (1,2,3,4-Tetrahydronaphthalen-1-yl)methyl 4-methylbenzenesulfonate (VI)

(1,2,3,4-Tetrahydronaphthalen-1-yl)methanol (V) was synthesized by reduction of 1,2,3,4tetrahydronaphthalen carboxylic acid following the procedure described for intermediate II. Yield 95\% ${ }^{1} \mathrm{H}$ NMR $\left(400 \mathrm{MHz} \mathrm{CDCl}_{3}\right) \delta 1.80-1.89\left(\mathrm{~m}, 2 \mathrm{H}, \mathrm{CH}_{2}\right) ; 2.02-2.11\left(\mathrm{~m}, 2 \mathrm{H}, \mathrm{CH}_{2}\right) ; 2.79-2.90\left(\mathrm{~m}, 3 \mathrm{H}, \mathrm{CH}_{2}\right.$ and $\mathrm{CH}) ; 3.90-3.96\left(\mathrm{~m}, 2 \mathrm{H}, \mathrm{CH}_{2} \mathrm{O}\right) ; 7.12-7.23(\mathrm{~m}, 4 \mathrm{H})$.

Then, to a solution of $\mathbf{V}$ in DCM was added Cl-Tos (2.0 eq), TEA (2.0 eq), and DMAP (0.7 eq). After 2 hour at room temperature, the solution was washed with brine. The organic layer was dried over anhydrous $\mathrm{Na}_{2} \mathrm{SO}_{4}$, filtered, concentrated and purified with flash chromatography in n-Exane/Ethyl acetate 30:20. The title compound VI was obtained in $61 \%$ yield. ${ }^{1} \mathrm{H}$ NMR $\left(400 \mathrm{MHz}, \mathrm{CDCl}_{3}\right) \delta 1.67$ $1.73\left(\mathrm{~m}, 2 \mathrm{H}, \mathrm{CH}_{2}\right) ; 1.85-1.91\left(\mathrm{~m}, 2 \mathrm{H}, \mathrm{CH}_{2}\right) ; 2.48\left(\mathrm{~s}, 3 \mathrm{H}, \mathrm{CH}_{3}\right) ; 2.68-2.74\left(\mathrm{~m}, 2 \mathrm{H}, \mathrm{CH}_{2}\right) ; 3.18(\mathrm{t}, 1 \mathrm{H}, J=$ $8.0 \mathrm{~Hz}, \mathrm{CH}) ; 4.07\left(\mathrm{t}, 1 \mathrm{H}, J=7.8 \mathrm{~Hz}, \mathrm{CH}_{2} \mathrm{O}\right) ; 4.21-4.26\left(\mathrm{~m}, 1 \mathrm{H}, \mathrm{CH}_{2} \mathrm{O}\right) ; 7.05-7.13(\mathrm{~m}, 4 \mathrm{H}) ; 7.36(\mathrm{~d}, 2 \mathrm{H}$, $J=8.0 \mathrm{~Hz}$, tosyl); $7.86(\mathrm{~d}, 2 \mathrm{H}, J=8.0 \mathrm{~Hz}$, tosyl $)$.

$\mathrm{N}-[(1,2,3,4$, Tetrahydronaphthalen-1-yl)methyl]-2-(1H-indol-3-yl)ethanamine (14).

A $10 \mathrm{~mL}$ sealable flask, equipped with a stir bar, was charged with 1 eq of tosylate VI, and 2.6 eq of tryptamine (13, Scheme 3), dissolved in THF. The flask was sealed, heated to $60-70^{\circ} \mathrm{C}$, and allowed to stir at that temperature overnight. The resulting slurry was cooled to room temperature, added with DCM and washed with brine. The organic layer solvents was dried over $\mathrm{Na}_{2} \mathrm{SO}_{4}$, filtered and evaporated under vacuum. The resulting mixture was separated by silica gel chromatography using DCM/MeOH 9/1 as eluent. Yield 69\%. ${ }^{1} \mathrm{H}$ NMR (400 MHz, $\left.\mathrm{CDCl}_{3}\right) \delta 1.68-1.71\left(\mathrm{~m}, 2 \mathrm{H}, \mathrm{CH}_{2}\right) ; 1.82-$ 
$1.85\left(\mathrm{~m}, 2 \mathrm{H}, \mathrm{CH}_{2}\right) ; 2.65-2.68\left(\mathrm{~m}, 2 \mathrm{H}, \mathrm{CH}_{2}\right) ; 3.02-3.05\left(\mathrm{~m}, 2 \mathrm{H}, \mathrm{CH}_{2}\right) ; 3.25-3.29\left(\mathrm{~m}, 5 \mathrm{H}, \mathrm{CH}\right.$ and $\left.2 \mathrm{CH}_{2}\right)$; $6.96(\mathrm{~d}, 1 \mathrm{H}, J=8.0 \mathrm{~Hz}) ; 7.00-7.14(\mathrm{~m}, 5 \mathrm{H}) ; 7.21(\mathrm{t}, 1 \mathrm{H}, J=8.4 \mathrm{~Hz}) ; 7.36(\mathrm{~d}, 1 \mathrm{H}, J=8.2 \mathrm{~Hz}) ; 7.62(\mathrm{~d}$, $1 \mathrm{H}, J=8.4 \mathrm{~Hz}) ; 8.08(\mathrm{~s}, 1 \mathrm{H}, \mathrm{NH}) ;{ }^{13} \mathrm{C} \mathrm{NMR}\left(100 \mathrm{MHz}, \mathrm{CDCl}_{3}\right) \delta 19.2 ; 22.8 ; 26.1 ; 29.3 ; 36.0 ; 49.1$; 54.1; 111.6; 113.0; 118.8, 120.0, 122.9, 123.1, 126.2, 126.8, 127.5, 128.7, 129.8; 136.0; 136.9, 143.7. ESIMS m/z calcd for $\mathrm{C}_{21} \mathrm{H}_{24} \mathrm{~N}_{2}, 304.19$; found $305.43\left(\mathrm{M}+\mathrm{H}^{+}\right)$

\section{General procedure for the synthesis of derivatives (15-22).}

Tryptamine (1.0 eq) was dissolved in a solution of DCM: $\mathrm{CH}_{3} \mathrm{COOH}(5: 1 \mathrm{v} / \mathrm{v})$ at room temperature. To this solution 2.0 equivalents of the proper aldheyde were added and the mixture was warmed to reflux for $1.5 \mathrm{~h}$. Then, 1.8 equivalents of sodium triacetoxyborohydride were added portionwise and the mixture was allowed to reflux for further $3-5 \mathrm{~h}$. After cooling to room temperature, $\mathrm{NaOH} 1 \mathrm{~N}$ was added. The organic phase was separated and extracted one more time with the alkaline solution. Then it was dried over $\mathrm{Na}_{2} \mathrm{SO}_{4}$, filtered and concentrated in vacuo. The crude products were purified by column chromatography using mixtures of $\mathrm{DCM} / \mathrm{MeOH}$ as eluent.

\section{2-(1H-Indol-3-yl)-N-(naphthalen-1-ylmethyl)ethanamine (15).}

Synthesized starting from 13 and 1-naphthaldehyde, yield 75\%. ${ }^{1} \mathrm{H}$ NMR $\left(400 \mathrm{MHz}, \mathrm{CDCl}_{3}\right) \delta 3.05(\mathrm{t}$, $\left.2 \mathrm{H}, J=6.8 \mathrm{~Hz}, \mathrm{CH}_{2}\right) ; 3.13\left(\mathrm{t}, 2 \mathrm{H}, J=6.8 \mathrm{~Hz}, \mathrm{CH}_{2}\right) ; 4.27\left(\mathrm{~s}, 2 \mathrm{H}, \mathrm{CH}_{2}\right) ; 6.97(\mathrm{~s}, 1 \mathrm{H}) ; 7.20(\mathrm{t}, 1 \mathrm{H}, J=7.2$ $\mathrm{Hz}) ; 7.33-7.48(\mathrm{~m}, 4 \mathrm{H}) ; 7.64(\mathrm{~d}, 1 \mathrm{H}, J=7.8 \mathrm{~Hz}) ; 7.74(\mathrm{~d}, 1 \mathrm{H}, J=8.2 \mathrm{~Hz}) ; 7.84(\mathrm{~d}, 1 \mathrm{H}, J=7.8 \mathrm{~Hz}) ; 8.00$ $(\mathrm{d}, 2 \mathrm{H}, J=4.0 \mathrm{~Hz}) .{ }^{13} \mathrm{C} \mathrm{NMR}\left(100 \mathrm{MHz}, \mathrm{CDCl}_{3}\right) \delta 25.7,49.8,51.4,111.1,113.9,118.9,119.3,121.9$, $122.0,123.5,125.4,125.5,125.9,126.0,127.4,127.7,128.7,131.7,133.8,135.7$. ESIMS $\mathrm{m} / \mathrm{z}$ calcd for $\mathrm{C}_{21} \mathrm{H}_{20} \mathrm{~N}_{2}, 300.16$; found $301.18\left(\mathrm{M}+\mathrm{H}^{+}\right)$.

\section{2-(1H-Indol-3-yl)-N-[(7-methoxynaphthalen-1-yl)methyl]ethanamine (16).}

Synthesized starting from 13 and 2-methoxy-1-naphthaldehyde, yield 63\%. ${ }^{1} \mathrm{H}$ NMR (400 MHz, $\left.\mathrm{CDCl}_{3}\right) \delta$ 3.05-3.09 (m, 4H, CH 2$) ; 3.61\left(\mathrm{~s}, 3 \mathrm{H}, \mathrm{CH}_{3}\right) ; 4.35$ (s, $\left.2 \mathrm{H}, \mathrm{CH}_{2}\right) ; 7.01-7.19(\mathrm{~m}, 3 \mathrm{H}) ; 7.28-7.44$ $(\mathrm{m}, 6 \mathrm{H}) ; 7.76(\mathrm{~d}, 1 \mathrm{H}, J=7.8 \mathrm{~Hz}) ; 7.90(\mathrm{~d}, 1 \mathrm{H}, J=7.0 \mathrm{~Hz}) ; 8.14(\mathrm{~s}, 1 \mathrm{H}, \mathrm{NH}) .{ }^{13} \mathrm{C}$ NMR $(100 \mathrm{MHz}$, 
$\left.\mathrm{CDCl}_{3}\right) \delta 25.1 ; 42.6 ; 48.1 ; 56.0 ; 94.6,111.4 ; 112.7 ; 119.0,119.6,122.3,122.7,122.9 ; 123.6 ; 127.3 ;$ $128.8 ; 129.9 ; 130.7 ; 131.7 ; 136.5,142.8$. ESIMS $\mathrm{m} / \mathrm{z}$ calcd for $\mathrm{C}_{21} \mathrm{H}_{20} \mathrm{~N}_{2} \mathrm{O} 330.17$; found 331.21 $\left(\mathrm{M}+\mathrm{H}^{+}\right)$.

\section{1-[(2-(1H-Indol-3-yl)ethyl)amino]methyl]naphthalen-2-ol (17).}

Synthesized starting from $\mathbf{1 3}$ and 2-hydroxy-1-naphthaldehyde, yield 51\%. ${ }^{1} \mathrm{H}$ NMR (400 MHz, $\left.\mathrm{CDCl}_{3}\right) \delta$ 3.05-3.09 (m, 4H, 2CH $) ; 4.41\left(\mathrm{~s}, 2 \mathrm{H}, \mathrm{CH}_{2}\right) ; 7.07-7.14(\mathrm{~m}, 3 \mathrm{H}) ; 7.20(\mathrm{t}, 1 \mathrm{H}, J=7.0 \mathrm{~Hz})$; 7.26-7.42 (m, 3H); $7.60(\mathrm{~d}, 1 \mathrm{H}, J=8.0 \mathrm{~Hz}) ; 7.65(\mathrm{~d}, 1 \mathrm{H}, J=8.0 \mathrm{~Hz}) ; 7.73(\mathrm{~d}, 2 \mathrm{H}, J=8.0 \mathrm{~Hz}) ; 8.08(\mathrm{~s}, 1 \mathrm{H}$, $\mathrm{NH}){ }^{13} \mathrm{C}$ NMR $\left(100 \mathrm{MHz}, \mathrm{CDCl}_{3}\right) \delta 25.2 ; 47.4 ; 48.7 ; 111.4 ; 111.5 ; 112.8 ; 113.0 ; 118.9,119.6,119.7$, $121.1,122.5 ; 122.6 ; 126.6 ; 127.5 ; 128.6 ; 129.0 ; 129.3 ; 131.9 ; 137.4,142.7$. ESIMS m/z calcd for $\mathrm{C}_{21} \mathrm{H}_{20} \mathrm{~N}_{2} \mathrm{O}, 316.16$; found $317.40\left(\mathrm{M}+\mathrm{H}^{+}\right)$.

\section{2-(1H-Indol-3-yl)-N-[(10-methylanthracen-9-yl)methyl]ethanamine (18).}

Synthesized starting from 13 and 10-methyl-9-anthracenecarbaldehyde, yield 58\%. ${ }^{1} \mathrm{H}$ NMR (400 $\left.\mathrm{MHz}, \mathrm{CDCl}_{3}\right) \delta 3.04-3.07\left(\mathrm{~m}, 4 \mathrm{H}, 2 \mathrm{CH}_{2}\right) ; 3.26\left(\mathrm{t}, 2 \mathrm{H}, J=6.4 \mathrm{~Hz}, \mathrm{CH}_{2}\right) ; 3.48\left(\mathrm{~s}, 3 \mathrm{H}, \mathrm{CH}_{3}\right) ; 6.92(\mathrm{~s}$, $1 \mathrm{H}) ; 7.10(\mathrm{t}, 1 \mathrm{H}, J=8.0 \mathrm{~Hz}) ; 7.20(\mathrm{t}, 1 \mathrm{H}, J=8.0 \mathrm{~Hz}) ; 7.32(\mathrm{~d}, 1 \mathrm{H}, J=8.0 \mathrm{~Hz}) ; 7.39(\mathrm{t}, 2 \mathrm{H}, J=7.8 \mathrm{~Hz})$; $7.46(\mathrm{t}, 2 \mathrm{H}, J=8.0 \mathrm{~Hz}, \operatorname{aryl}) ; 7.56(\mathrm{~d}, 1 \mathrm{H}, J=8.0 \mathrm{~Hz}) ; 7.95(\mathrm{~s}, 1 \mathrm{H}, \mathrm{NH}) ; 8.19$ (d, 2H, J=8.0 Hz); 8.29 (d, $2 \mathrm{H}, J=8.0 \mathrm{~Hz}) .{ }^{13} \mathrm{C} \mathrm{NMR}\left(100 \mathrm{MHz}, \mathrm{CDCl}_{3}\right) \delta 17.1 ; 25.5 ; 45.6 ; 49.7 ; 111.4 ; 111.5 ; 112.2 ; 113.0 ; 119.7$, 122.2, 122.4, 124.6; 125.0; 125.7; 125.9; 136.5; 142.7. ESIMS $\mathrm{m} / \mathrm{z}$ calcd for $\mathrm{C}_{26} \mathrm{H}_{24} \mathrm{~N}_{2}, 364.19$ found $365.48\left(\mathrm{M}+\mathrm{H}^{+}\right)$.

5[(2-(1H-Indol-3-yl)ethylamino)methyl]-2-methoxyphenol (19).

Synthesized starting from 13 and vanillin, yield 58\%. ${ }^{1} \mathrm{H}$ NMR (400 MHz, $\left.\mathrm{CD}_{3} \mathrm{OD}\right) \delta 2.84$ (t, $2 \mathrm{H}$, $\mathrm{CH}_{2}, J=7.4 \mathrm{~Hz}$ ); $2.92\left(\mathrm{t}, 2 \mathrm{H}, \mathrm{CH} H_{2}, J=7.4 \mathrm{~Hz}\right) ; 3.59\left(\mathrm{~s}, 2 \mathrm{H}, \mathrm{CH}_{2}\right) ; 3.67$ (s, $\left.3 \mathrm{H}, \mathrm{CH}_{3}\right) ; 6.61(\mathrm{~d}, 1 \mathrm{H}, J=8.0$ $\mathrm{Hz}) ; 6.71(\mathrm{~s}, 1 \mathrm{H}) ; 6.73(\mathrm{~d}, 1 \mathrm{H}, J=8.0 \mathrm{~Hz}) ; 6.94-6.98(\mathrm{~m}, 2 \mathrm{H}) ; 7.05(\mathrm{t}, 1 \mathrm{H}, J=8.0 \mathrm{~Hz}) ; 7.31(\mathrm{~d}, 1 \mathrm{H}$, $J=8.0 \mathrm{~Hz}) ; 7.48(\mathrm{~d}, 1 \mathrm{H}, J=8.0 \mathrm{~Hz}) .{ }^{13} \mathrm{C} \mathrm{NMR}\left(100 \mathrm{MHz}, \mathrm{CD}_{3} \mathrm{OD}\right) \delta 24.7,48.6,52.8,55.1,111.2$, 
$111.8,112.1,115.0,118.2,121.2,121.3,122.4,122.5,127.4,130.1,137.0,145.9,147.9$. ESIMS m/z calcd for $\mathrm{C}_{18} \mathrm{H}_{20} \mathrm{~N}_{2} \mathrm{O}_{2}, 296.15$; found $297.16\left(\mathrm{M}+\mathrm{H}^{+}\right)$.

N-(3,4-Dimethoxybenzyl)-2-(1H-indol-3-yl)ethanamine (20).

Synthesized starting from 13 and 3,4-dimethoxybenzaldehyde, yield 72\%. ${ }^{1} \mathrm{H}$ NMR $\left(400 \mathrm{MHz}, \mathrm{CDCl}_{3}\right)$ $\delta 3.01-3.15\left(\mathrm{~m}, 4 \mathrm{H}, 2 \mathrm{CH}_{2}\right) ; 3.80\left(\mathrm{~s}, 2 \mathrm{H}, \mathrm{CH}_{2}\right) ; 3.82\left(\mathrm{~s}, 6 \mathrm{H}, 2 \mathrm{CH}_{3}\right) ; 6.75(\mathrm{~d}, 1 \mathrm{H}, J=8.0 \mathrm{~Hz}) ; 6.81(\mathrm{~d}, 1 \mathrm{H}$, $J=8.0 \mathrm{~Hz}) ; 6.88(\mathrm{~s}, 1 \mathrm{H}) ; 7.03(\mathrm{~s}, 1 \mathrm{H}) ; 7.10(\mathrm{t}, 1 \mathrm{H}, J=4.0 \mathrm{~Hz}) ; 7.18(\mathrm{t}, 1 \mathrm{H}, J=4.0 \mathrm{~Hz}) ; 7.35(\mathrm{~d}, 1 \mathrm{H}, J=8.0$ $\mathrm{Hz}) ; 7.58(\mathrm{~d}, 1 \mathrm{H}, J=8.0 \mathrm{~Hz}) ; 8.10(\mathrm{~s}, 1 \mathrm{H}, \mathrm{NH}) .{ }^{13} \mathrm{C} \mathrm{NMR}\left(100 \mathrm{MHz}, \mathrm{CDCl}_{3}\right) \delta 25.4 ; 49.0 ; 53.5 ; 56.0$; $111.0,111.4 ; 111.5 ; 112.7 ; 119.0,119.5,120.8,122.3 ; 122.4 ; 127.4 ; 130.1 ; 137.0 ; 145.9,147.9$. ESIMS m/z calcd for $\mathrm{C}_{19} \mathrm{H}_{22} \mathrm{~N}_{2} \mathrm{O}_{2}, 310.17$; found $311.25\left(\mathrm{M}+\mathrm{H}^{+}\right)$.

\section{2-(1H-Indol-3-yl)-N-(4-phenoxybenzyl)ethanamine (21)}

Synthesized starting from 13 and 4-phenoxybenzaldehyde, yield 83\%. ${ }^{1} \mathrm{H}$ NMR (400 MHz, $\mathrm{CD}_{3} \mathrm{OD}$ ) $\delta$ $3.12\left(\mathrm{t}, 2 \mathrm{H}, \mathrm{CH}_{2}, J=8.8 \mathrm{~Hz}\right) ; 3.24\left(\mathrm{t}, 2 \mathrm{H}, \mathrm{CH}_{2}, J=8.4 \mathrm{~Hz}\right) ; 4.08\left(\mathrm{~s}, 2 \mathrm{H}, \mathrm{CH}_{2}\right) ; 6.95-7.05(\mathrm{~m}, 5 \mathrm{H}) ; 7.10-$ $7.18(\mathrm{~m}, 3 \mathrm{H}) ; 7.31-7.42(\mathrm{~m}, 5 \mathrm{H}) ; 7.53(\mathrm{~d}, 1 \mathrm{H}, J=8.0 \mathrm{~Hz}) .{ }^{13} \mathrm{C} \mathrm{NMR}\left(100 \mathrm{MHz}, \mathrm{CD}_{3} \mathrm{OD}\right) \delta 24.5 ; 50.7$; $52.7 ; 111.4 ; 113.4 ; 119.8 ; 120.6 ; 120.9,121.3,123.6,124.9 ; 125.9 ; 128.8 ; 129.0 ; 131.9 ; 133.4 ; 139.2 ;$ 158.8, 160.8. ESIMS m/z calcd for $\mathrm{C}_{23} \mathrm{H}_{22} \mathrm{~N}_{2} \mathrm{O}, 342.17$; found 343. $25\left(\mathrm{M}+\mathrm{H}^{+}\right)$

\section{N-Methyl-2-(1-methyl-1H-indol-3-yl)-N-(4-phenoxybenzyl)ethanamine (22)}

Compound 21 ( 1 eq) was dissolved in a mixture of anhydrous DCM/DMF $(2 / 1 \mathrm{v} / \mathrm{v})$ under magnetic stirring and the temperature was set to $0^{\circ} \mathrm{C}$. To this solution, 3 equivalents of $\mathrm{NaH}$ were added portionwise and the mixture was allowed to react for 30 minutes. Then, 3 equivalents of methyl iodide in dry DCM were added dropwise and the reaction was warmed to room temperature and maintained under stirring for further $12 \mathrm{~h}$. Then, reaction was quenched by $10 \%$ aqueous solution of citric acid and washed with brine. Organic layer was separated, dried over anhydrous $\mathrm{Na}_{2} \mathrm{SO}_{4}$, filtered and evaporated in vacuo. Crude product was purified by column chromatography using DCM/MeOH (9:1 v:v) as mobile phase. ${ }^{1} \mathrm{H}$ NMR $\left(400 \mathrm{MHz}, \mathrm{CDCl}_{3}\right) \delta 3.14-3.18\left(\mathrm{~m}, 5 \mathrm{H}, \mathrm{CH}_{3}\right.$ and $\left.\mathrm{CH}_{2}\right) ; 3.78\left(\mathrm{~s}, 3 \mathrm{H}, \mathrm{CH}_{3}\right) ; 3.84$ 
(t, $\left.2 \mathrm{H}, J=8.0 \mathrm{~Hz}, \mathrm{CH}_{2}\right) ; 4.99$ (s, 2H, $\left.\mathrm{CH}_{2}\right) ; 6.95(\mathrm{~d}, 2 \mathrm{H}, J=8.0 \mathrm{~Hz}) ; 7.05(\mathrm{~d}, 2 \mathrm{H}, J=8.0 \mathrm{~Hz}) ; 7.17(\mathrm{t}, 1 \mathrm{H}$, $J=7.6 \mathrm{~Hz}) ; 7.18-7.24(\mathrm{~m}, 4 \mathrm{H}) ; 7.35(\mathrm{t}, 2 \mathrm{H}, J=8.0 \mathrm{~Hz}) ; 7.59(\mathrm{~d}, 3 \mathrm{H}, J=8.0 \mathrm{~Hz}) .{ }^{13} \mathrm{C}$ NMR $(100 \mathrm{MHz}$, $\left.\mathrm{CDCl}_{3}\right) \delta 19.3,32.8,49.7,63.7,67.0,109.5,118.2,118.4,119.3,119.9,120.7,121.9,124.5,126.9$, 128.2, 130.0, 134.8, 136.8, 155.4, 159.9. ESIMS m/z calcd for $\mathrm{C}_{25} \mathrm{H}_{26} \mathrm{~N}_{2} \mathrm{O}, 370.49$; found 371.55 $\left(\mathrm{M}+\mathrm{H}^{+}\right)$.

\section{Pharmacology}

\section{Cell culture and transfections}

For fluorescence assays, cells stably expressing TRP channels (SH-SY5Y for TRPV1, HEK for TRPM8 and IMR90 for TRPA1) were cultured in a monolayer at $37^{\circ} \mathrm{C}$ in a humidified atmosphere of 5\% $\mathrm{CO}_{2}$ in Earle's minimum essential medium with Earle's salts supplemented with $10 \%$ fetal calf serum, $1 \%$ nonessential amino acids, $2 \mathrm{mM} \mathrm{L-glutamine,} 100 \mu \mathrm{g}$ streptomycin/ml, $100 \mathrm{U}$ penicillin $/ \mathrm{ml}$, and the correspondent antibiotic for each stable cell line $(0.4 \mu \mathrm{g} / \mathrm{ml}$ puromycin for Sh-SY5Y and 400 $\mu \mathrm{g} / \mathrm{ml} \mathrm{G} 418$ for HEK-CR1).

For electrophysiological experiments, HEK293 cells were grown in 100-mm plastic Petri dishes in Dulbecco's modified Eagle medium containing 10\% fetal bovine serum, penicillin (100 U/ml), and streptomycin $(100 \mathrm{U} / \mathrm{ml})$ in a humidified atmosphere at $37^{\circ} \mathrm{C}$ with $5 \% \mathrm{CO}_{2}$. The cells were seeded on glass coverslips (Carolina Biological Supply Company, Burlington, NC) and transfected the next day with $3.6 \mu \mathrm{g}$ rat TRPM8 receptor cDNA (a gift from Dr. Felix Viana, Alicante Institute of Neuroscience, Elche, Spain) using Lipofectamine 2000 (Invitrogen, Milan, Italy). A plasmid encoding for the Enhanced Green Fluorescent Protein (Clontech, Palo Alto, CA) was used as a transfection marker. Total cDNA in the transfection mixture was kept constant at $4 \mu \mathrm{g}$.

\section{Fluorescence assays.}


For fluorescence assays, the cells were seeded in 96-well plates (Corning Incorporated, Corning, NY) at a cell density of 40,000 cells 2 days before treatment. The day of treatment the medium was replaced with $100 \mu \mathrm{L}$ of the dye loading solution Fluo-4 NW supplemented with probenecid 2.5 $\mathrm{mM}$. Then the tested molecules dissolved in DMSO were added at the desired concentrations and the plate(s) were incubated in darkness at $37^{\circ} \mathrm{C}$ in a humidified atmosphere of $5 \%$ $\mathrm{CO}_{2}$ for 60 minutes. The fluorescence was measure using instrument settings appropriate for excitation at $485 \mathrm{~nm}$ and emission at $535 \mathrm{~nm}$. (POLARstar Omega BMG LAB tech). A baseline recording of 4 cycles was recorded prior to stimulation with the agonist $(10 \mu \mathrm{M}$ capsaicin for TRPV1, $100 \mu \mathrm{M}$ menthol for TRPM8, and $100 \mu \mathrm{M}$ AITC for TRPA1). Each antagonist (10 $\mu \mathrm{M}$ Ruthenium Red for TRPV1 and TRPA1, $10 \mu \mathrm{M}$ AMTB for TRPM8) was added to the medium containing the corresponding agonist to induce channel blockade. The changes in fluorescence intensity were recorded during 15 cycles more. The higher concentration of DMSO used in the experiment, was added to the control wells.

The cells fluorescence was measured before and after the addition of various concentrations of test compounds $\left(\lambda_{\mathrm{EX}}=488 \mathrm{~nm}, \lambda_{\mathrm{EM}}=516 \mathrm{~nm}\right)$. The fluorescence values obtained are normalized to that prompted by the corresponding agonist (for channel activating compounds) or upon agonist+antagonist co-exposure (for channel blocker compounds).

\section{Whole-cell electrophysiology}

Macroscopic currents from transiently transfected HEK293 cells were recorded at room temperature 1 day after transfection, with an Axopatch 200B amplifier (Molecular Devices, Union City, CA) using the whole-cell configuration of the patch-clamp technique, with glass micropipettes of 3-5 $\mathrm{M} \Omega$ resistance. The extracellular solution contained (mM): $138 \mathrm{NaCl}, 2 \mathrm{CaCl}_{2}, 5.4 \mathrm{KCl}, 1 \mathrm{MgCl}_{2}$, 10 glucose, and 10 HEPES, pH 7.4 with $\mathrm{NaOH}$. The pipette (intracellular) solution contained (mM): 
$140 \mathrm{CsCl}, 1 \mathrm{EGTA}, 10 \mathrm{HEPES}$, and $5 \mathrm{Mg}$-ATP, pH 7.3-7.4 with CsOH. The pCLAMP software (version 10.2; Molecular Devices) was used for data acquisition and analysis. Linear cell capacitance (C) was determined by integrating the area under the whole-cell capacity transients, evoked by short (5$10 \mathrm{~ms}$ ) pulses from -80 to $-75 \mathrm{mV}$ with the whole-cell capacitance compensation circuit of the Axopatch 200B turned off. Data were acquired at $5 \mathrm{kHz}$ and filtered at $1-5 \mathrm{kHz}$ with the four-pole lowpass Bessel filter of the amplifier. No corrections were made for liquid junction potentials. Currents were evoked by consecutive voltage ramps from -100 to $+100 \mathrm{mV}$ in $100 \mathrm{~ms}$, delivered every 4 seconds. Current densities (expressed in $\mathrm{pA} / \mathrm{pF}$ ) were calculated at $+80 \mathrm{mV}$ or $-80 \mathrm{mV}$ and divided by C.

\section{Chemical modulators}

1-Menthol and BCTC were purchased from Applichem Panreac (Barcelona, Spain) and Tocris Bioscience (Bristol, UK), respectively; AITC, Capsaicin and ruthenium red were purchased from Sigma-Aldrich (St.Louis, MO, USA). These compounds were dissolved in DMSO (final concentration $\leq 1 \%$ ). In each experiment, the same volume of solvent used for tested drugs was added to the control solution. Fast solution exchanges ( $<1 \mathrm{~s})$ were achieved by means of a cFlow 8 flow controller attached to a cF-8VS 8-valve switching apparatus, as previously described. ${ }^{37}$

\section{Molecular modeling}

\section{Protein and ligands preparations}

The TRPM8 homology model ${ }^{30}$ was prepared using the Protein Preparation ${ }^{38,39}$ utility in order to obtain satisfactory starting structures for the following studies. This utility is meant to ensure chemical correctness and to optimize protein structures for further analysis. In particular, Epik ${ }^{40}$ was 
then used to predict ionization and tautomeric states for the ligands using a $\mathrm{pH}$ of $7 \pm 1$. Successively, optimization of the hydrogen-bonding network was obtained by reorienting hydroxyl and thiol groups, amide groups of Asn and Gln, and His rings. The ionization and tautomeric states of His, Asp, Glu, Arg and Lys were adjusted to match a $\mathrm{pH}$ of 7.4. The structure was finally submitted to a restrained minimization (OPLS2005 force field) ${ }^{41}$ that was stopped when RMSD of heavy atoms reached $0.30 \AA$. Ligands were sketched using the Maestro ${ }^{42}$ interface and 3D coordinates were generated using LigPrep $^{43}$ Ionization/tautomeric states were predicted for a $\mathrm{pH}$ range of $7 \pm 1$ using Epik. ${ }^{40}$ The most populated ionization state for each ligand was retained.

\section{Sitemap calculations}

All TRPM8 atoms were considered in the identification the top ranking potential binding sites. Each site was required to have at least 5 site points and was cropped at $4 \AA$ from the nearest site point. The definition of hydrophobicity was set to "restrictive".

\section{Molecular docking}

Docking of 12 and 21 was performed using Glide $\mathrm{SP}^{44-46}$ and $\mathrm{XP}^{47}$ in a stepwise manner. The docking spaces was defined as as a $50 \AA^{3}$ cubic box, while the diameter midpoint of docked ligands was required to remain within a smaller, nested $30 \AA^{3}$ cubic box centered on the centroid of BP1 site points. Receptor $\mathrm{OH}$ and $\mathrm{SH}$ groups were set free to rotate. Two docking grids were used for SP and XP docking, differing for the scaling of vdW radii for non polar receptor atoms only. For SP a coefficient of 0.85 was used, while no scaling was used for XP.

At most ten poses for each ligand were retrieved from the SP docking, discarding as duplicates poses that showed both RMS deviation less than $1.5 \AA$ and maximum atomic displacement less than $2.0 \AA$. These poses were then refined, rescored and minimized using Glide XP. The best scoring XP pose for each ligand was then retained for the MD simulations.

\section{Molecular dynamics simulation}


MD simulations of TRPM8/12 and TRPM8/21 complexes were set and run using Desmond MD system $^{48-50}$. The simulated environment was built using the system builder utility, with the structures being neutralized by $\mathrm{Cl}^{-}$ions. The small 903-924 fragment was removed. With the exception of the 954-1016 fragment, which was uncostrained, the protein backbone was constrained by a $1 \mathrm{kcal} / \mathrm{mol}$ force. Octanol was used as explicit solvent. Before performing the simulations, a series of minimizations and short MD simulations were carried out to relax the model system, by means of a relaxation protocol consisting of six stages: (i) minimization with the solute restrained; (ii) minimization without restraints; (iii) simulation (12 ps) in the NVT ensemble using a Berendsen thermostat $(10 \mathrm{~K})$ with non-hydrogen solute atoms restrained; (iv) simulation (12 ps) in the NPT ensemble using a Berendsen thermostat $(10 \mathrm{~K})$ and a Berendsen barostat $(1 \mathrm{~atm})$ with non-hydrogen solute atoms restrained; (v) simulation (24 ps) in the NPT ensemble using a Berendsen thermostat (300 K) and a Berendsen barostat (1 atm) with non-hydrogen solute atoms restrained; (vi) unrestrained simulation (24 ps) in the NPT ensemble using a Berendsen thermostat (300 K) and a Berendsen barostat (1 atm). At this point, $12 \mathrm{~ns}$ long MD simulations were carried out at a temperature of $300^{\circ} \mathrm{K}$ in the NPT ensemble using a Nose-Hoover chain thermostat and a Martyna-Tobias-Klein barostat (1.01325 bar). Trajectory analyses were performed using the Desmond simulation event analysis tool for the RMSD calculations, Desmond Simulation Interaction diagram tool for the Ligand Interaction analysis and Schrodinger clustering of conformers script for the bound conformation analysis.

\section{Pharmacophore modeling}

Docking/MD predicted bound conformations were used to manually build the pharmacophore models summarizing the chemical feature of tryptamine based agonists and antagonists. Models were built using the software Phase ${ }^{51-53}$ Features and their coordinates were automatically detected using the ligand-based option of Phase and were then edited in freestyle modes according to the ligand-protein interaction detected by the Simulation Interaction diagram tool. In particular, $\mathrm{H} 1$ and $\mathrm{H} 2$ features were 
previously detected as aromatic features, but were changed to hydrophobic since during the MD trajectories they interacted with non aromatic hydrophobic residues only. For the same reason, the R3 feature of the antagonist model was changed to H1. After the model generation and refinement phase was used to evaluate the fitness of the tryptamine based agonists and antagonists on the two models as reported in Table $\mathrm{S} 1$.

\section{Statistical analysis}

Data are expressed as mean \pm SEM. Statistically significant differences were evaluated with the Student $t$ test or with ANOVA followed by the Student-Newman-Keuls test, with the threshold set at $\mathrm{p}<0.05$.

\section{ASSOCIATED CONTENTS:}

\section{Supporting Information.}

Scheme for the synthesis of intermediates 4-phenylbenzyl iodide (III) and 1,2,3,4-

tetrahydronaphthalen-4-yl)methyl 4-methylbenzenesulfonate (IV). Sitemap graphical output for BP1.

Fittings of the tryptamine-based agonists and antagonists on the respective pharmacophore models.

Qualitative HPLC runs for derivatives 4-12 and 14- 22

\section{AUTHOR INFORMATIONS}

\section{Corresponding authors:}

*I.M.G.M., Tel: +39-081-678633; email address: imgomez@ unina.it

*P.C., Tel:+39-089-969242; email address pcampigl@unisa.it

\section{Author Contributions}
A.B. , C.O., and P.A. equally contributed to this work. 


\section{ABREVIATIONS}

TRP box, structuralmotif in the cytosolic C-terminus domain of TRP channel; VSD voltage sensor domain of TRP channels; DCM, dichloromethane; DMF, dimethylformamide; NaH, hydride sodium; THF, tetrahydrofuran; TEA, triethylamine; mW, microwave; TRPV1, transient receptor potential cation channel subfamily V member 1; TRPA1, transient receptor potential cation channel, subfamily A, member 1; AITC, allyl isothiocyanate; BCTC, N-(4-tert-butylphenyl)-4-(3-chloropyridin-2yl)piperazine-1-carboxamide; BP1, potential binding site; SEM, standard error of the mean; MS, mass spectrometry; ESI, electrospray ionization; MeOH methanol; DMSO, dimethylsulfoxide; HEPES, 4-(2hydroxyethyl)-1-piperazineethanesulfonic acid; EGTA, ethylene glycol tetraacetic acid; RMSD, rootmean-square deviation. 


\section{References}

(1) Peier, A. M.; Moqrich, A.; Hergarden, A. C.; Reeve, A. J.; Andersson, D. A.; Story, G. M.; Earley, T. J.; Dragoni, I.; McIntyre, P.; Bevan, S.; Patapoutian, A. A TRP channel that senses cold stimuli and menthol. Cell 2002, 108, 705-715.

(2) Proudfoot, C. J.; Garry, E. M.; Cottrell, D. F.; Rosie, R.; Anderson, H.; Robertson, D. C.; Fleetwood-Walker, S. M.; Mitchell, R. Analgesia mediated by the TRPM8 cold receptor in chronic neuropathic pain. Curr. Biol. 2006, 16, 1591-1605.

(3) Knowlton, W. M.; Daniels, R. L.; Palkar, R.; McCoy, D. D.; McKemy, D. D. Pharmacological blockade of TRPM8 ion channels alters cold and cold pain responses in mice. PloS one 2011, 6, e25894.

(4) Varrassi, G.; Muller-Schwefe, G.; Pergolizzi, J.; Oronska, A.; Morlion, B.; Mavrocordatos, P.; Margarit, C.; Mangas, C.; Jaksch, W.; Huygen, F.; Collett, B.; Berti, M.; Aldington, D.; Ahlbeck, K. Pharmacological treatment of chronic pain - the need for CHANGE. Curr. Med. Res.Opin. 2010, 26, 1231-1245.

(5) Zhang, L.; Barritt, G. J. Evidence that TRPM8 is an androgen-dependent Ca2+ channel required for the survival of prostate cancer cells. Cancer Res. 2004, 64, 8365-8373.

(6) Beck, B.; Bidaux, G.; Bavencoffe, A.; Lemonnier, L.; Thebault, S.; Shuba, Y.; Barrit, G.; Skryma, R.; Prevarskaya, N. Prospects for prostate cancer imaging and therapy using high-affinity TRPM8 activators. Cell Calcium 2007, 41, 285-294.

(7) Dhennin-Duthille, I.; Gautier, M.; Faouzi, M.; Guilbert, A.; Brevet, M.; Vaudry, D.; Ahidouch, A.; Sevestre, H.; Ouadid-Ahidouch, H. High expression of transient receptor potential channels in 
human breast cancer epithelial cells and tissues: correlation with pathological parameters. Cell. Physiol. Biochem. 2011, 28, 813-822.

(8) Ouadid-Ahidouch, H.; Dhennin-Duthille, I.; Gautier, M.; Sevestre, H.; Ahidouch, A. TRP calcium channel and breast cancer: expression, role and correlation with clinical parameters. Bull. Cancer 2012, 99, 655-664.

(9) Yee, N. S.; Zhou, W.; Lee, M. Transient receptor potential channel TRPM8 is over-expressed and required for cellular proliferation in pancreatic adenocarcinoma. Cancer Lett. 2010, 297, 49-55.

(10) Yamamura, H.; Ugawa, S.; Ueda, T.; Morita, A.; Shimada, S. TRPM8 activation suppresses cellular viability in human melanoma. Am. J. Physiol. Cell Physiol. 2008, 295, C296-C301.

(11) Lashinger, E. S.; Steiginga, M. S.; Hieble, J. P.; Leon, L. A.; Gardner, S. D.; Nagilla, R.; Davenport, E. A.; Hoffman, B. E.; Laping, N. J.; Su, X. AMTB, a TRPM8 channel blocker: evidence in rats for activity in overactive bladder and painful bladder syndrome. Am. J. Physiol. Renal Physiol. 2008, 295, F803-F810.

(12) Andersson, K. E.; Gratzke, C.; Hedlund, P. The role of the transient receptor potential (TRP) superfamily of cation-selective channels in the management of the overactive bladder. BJU Int. 2010, 106, 1114-1127.

(13) Fernández-Peña, C.; Viana, F. Targeting TRPM8 for Pain Relief. Open Pain J. 2013, 6, 154164.

(14) Parra, A.; Madrid, R.; Echevarria, D.; del Olmo, S.; Morenilla-Palao, C.; Carmen Acosta, M.; Gallar, J.; Dhaka, A.; Viana, F.; Belmonte, C. Ocular surface wetness is regulated by TRPM8dependent cold thermoreceptors of the cornea. Nat. Med. 2010, 16, 1396-1399. 
(15) Foster, A.; Van Der Logt, C. P. E.; Tareilus, E. W. Tetrahydropyrimidine-2-one derivatives and their uses. Unilever Plc (GB) WO2004026840, 2005.

(16) Bassoli, A.; Borgonovo, G.; Busnelli, G.; Morini, G. Synthesis of a new family of N-aryl lactams active on chemesthesis and taste. Eur. J. Org. Chem 2006, 2006, 1656-1663.

(17) Calvo, R.; Chen, J.; Illig, C.; Meegalla, S.; Parks, D.; Parsons, W.; Player, M. R. Substituted benzimdazole derivatives useful as trpm8 receptor modulators. Janssenn Pharmaceutica $N V(B E)$ WO2012109100, 2012.

(18) Irlapati, N. R.; Thomas, A.; Kurhe, D. K.; Shelke, S. Y.; Khairatkar, J. N.; Viswanadha, S.; Mukhopadhyay, I. Fused oxazole and thiazole derivatives as trpms modulators. Glenmark Pharmaceutical SA(CH) WO2010010435, 2010.

(19) Tamayo, N. A.; Bo, Y.; Gore, V.; Ma, V.; Nishimura, N.; Tang, P.; Deng, H.; Klionsky, L.; Lehto, S. G.; Wang, W.; Youngblood, B.; Chen, J.; Correll, T. L.; Bartberger, M. D.; Gavva, N. R.; Norman, M. H. Fused piperidines as a novel class of potent and orally available transient receptor potential melastatin type 8 (TRPM8) antagonists. J .Med. Chem. 2012, 55, 1593-1611.

(20) Zhu, B.; Xia, M.; Xu, X.; Ludovici, D. W.; Tennakoon, M.; Youngman, M. A.; Matthews, J. M.; Dax, S. L.; Colburn, R. W.; Qin, N.; Hutchinson, T. L.; Lubin, M. L.; Brandt, M. R.; Stone, D. J.; Flores, C. M.; Macielag, M. J. Arylglycine derivatives as potent transient receptor potential melastatin 8 (TRPM8) antagonists. Bioor. Med. Chem. Lett. 2013, 23, 2234-2237.

(21) Ostacolo, C.; Ambrosino, P.; Russo, R.; Lo Monte, M.; Soldovieri, M. V.; Laneri, S.; Sacchi, A.; Vistoli, G.; Taglialatela, M.; Calignano, A. Isoxazole derivatives as potent transient receptor potential melastatin type 8 (TRPM8) agonists. Eur. J. Med. Chem. 2013, 69, 659-669. 
(22) Ferrer-Montiel, A.; Fernandez-Carvajal, A.; Planells-Cases, R.; Fernandez-Ballester, G.;

Gonzalez-Ros, J. M.; Messeguer, A.; Gonzalez-Muniz, R. Advances in modulating thermosensory TRP channels. Expert Opin. Ther. Pat. 2012, 22, 999-1017.

(23) Than, J. Y.; Li, L.; Hasan, R.; Zhang, X. Excitation and modulation of TRPA1, TRPV1, and TRPM8 channel-expressing sensory neurons by the pruritogen chloroquine. J. Biol. Chem. 2013, $288,12818-12827$.

(24) Weil, A.; Moore, S. E.; Waite, N. J.; Randall, A.; Gunthorpe, M. J. Conservation of functional and pharmacological properties in the distantly related temperature sensors TRVP1 and TRPM8. Mol. Pharmacol. 2005, 68, 518-527.

(25) Terada, Y.; Kitajima, M.; Taguchi, F.; Takayama, H.; Horie, S.; Watanabe, T. Identification of indole alkaloid structural units important for stimulus-selective TRPM8 inhibition: SAR study of naturally occurring iboga derivatives. J. Nat. Prod. 2014, 77, 1831-1838

(26) DeFalco, J.; Steiger, D.; Dourado, M.; Emerling, D.; Duncton, M. A. 5-benzyloxytryptamine as an antagonist of TRPM8. Bioorg. Med. Chem. Lett. 2010, 20, 7076-7079.

(27) Campiglia, P.; Aquino, C.; Bertamino, A.; Sala, M.; Gomez-Monterrey, I. M.; Novellino, E.; Grieco, P. Novel route in the synthesis of $\psi[\mathrm{CH} 2 \mathrm{NH}]$ amide bond surrogate. Tetrahedron Lett. 2008, 49, 731-734.

(28) Fürstner, A.; Langemann, K. Macrocycles by ring-closing metathesis. Synthesis 1997, 1997, 792-803. 
(29) Bautista, D. M.; Siemens, J.; Glazer, J. M.; Tsuruda, P. R.; Basbaum, A. I.; Stucky, C. L.; Jordt, S. E.; Julius, D. The menthol receptor TRPM8 is the principal detector of environmental cold. Nature 2007, 448, 204-208.

(30) McKemy, D. D.; Neuhausser, W. M.; Julius, D. Identification of a cold receptor reveals a general role for TRP channels in thermosensation. Nature 2002, 416, 52-58.

(31) Andersson, D. A.; Chase, H. W.; Bevan, S. TRPM8 activation by menthol, icilin, and cold is differentially modulated by intracellular pH. J. Neurosci. 2004, 24, 5364-5369.

(32) Behrendt, H. J.; Germann, T.; Gillen, C.; Hatt, H.; Jostock, R. Characterization of the mouse cold-menthol receptor TRPM8 and vanilloid receptor type-1 VR1 using a fluorometric imaging plate reader (FLIPR) assay. Br. J. Pharmacol. 2004, 141, 737-745.

(33) Malkia, A.; Madrid, R.; Meseguer, V.; de la Pena, E.; Valero, M.; Belmonte, C.; Viana, F. Bidirectional shifts of TRPM8 channel gating by temperature and chemical agents modulate the cold sensitivity of mammalian thermoreceptors. J. Physiol. 2007, 581, 155-174.

(34) Taberner, F. J.; López-Córdoba, A.; Fernández-Ballester, G.; Korchev, Y.; Ferrer-Montiel, A. The region adjacent to the $\mathrm{C}$-end of the inner gate in transient receptor potential melastatin 8 (TRPM8) channels plays a central role in allosteric channel activation. J. Biol. Chem. 2014, 289, $28579-28594$.

(35) Liao, M.; Cao, E.; Julius, D.; Cheng, Y. Structure of the TRPV1 ion channel determined by electron cryo-microscopy. Nature 2013, 504, 107-112.

(36) SiteMap; Schrödinger LLC, New York, 2015 
(37) Ambrosino P.; Soldovieri M.V.; De Maria M.; Russo C.; Taglialatela M. Functional and biochemical interaction between PPAR $\alpha$ receptors and TRPV1 channels: Potential role in PPAR $\alpha$ agonists-mediated analgesia. Pharmacol. Res. 2014, 87, 113-122

(38) Madhavi Sastry G.; Adzhigirey M.; Day T.; Annabhimoju R; Sherman W. Protein and ligand preparation: Parameters, protocols, and influence on virtual screening enrichments. J. Comput. Aided Mol. Des. 2013, 27, 221-234.

(39) Protein Preparation Wizard; Schrödinger LLC, New York, 2015.

(40) Epik; Schrödinger LLC, New York, 2015.

(41) Jorgensen W.L.; Maxwell D.S.; Tirado-Rives J. Development and testing of the OPLS all atom force field on conformational energetics and properties of organic liquids. J. Am. Chem. Soc. 1996, $118,11225-11236$.

(42) Maestro; Schrödinger LLC, New York, 2015.

(43) LigPrep; Schrödinger LLC, New York, 2015.

(44) Halgren T.A.; Murphy R.B.; Friesner R.A.; Beard H.S.; Frye L.L.; Pollard W.T.; Banks J.L. Glide: a new approach for rapid, accurate docking and scoring. 2. Enrichment factors in database screening. J. Med. Chem. 2004, 47, 1750-1759 .

(45) Friesner R.A.; Banks J.L.; Murphy R.B.; Halgren T.A.; Klicic J.J.; Mainz D.T.; Repasky M.P.; Knoll E.H.; Shelley M.; Perry J.K.; Shaw D.E.; Francis P.; Shenkin P.S.. Glide: a new approach for rapid, accurate docking and scoring. 1. Method and assessment of docking accuracy. J. Med. Chem. 2004, 47, 1739-1749.

(46) Glide; Schrödinger LLC, New York, 2015. 
(47) Friesner R.A.; Murphy R.B.; Repasky M.P.; Frye L.L.; Greenwood J.R.; Halgren T.A.; Sanschagrin P.C.; Mainz D.T. Extra precision glide: Docking and scoring incorporating a model of hydrophobic enclosure for protein-ligand complexes. J. Med. Chem. 2006, 49, 61776196.

(48) Desmond Molecular Dynamics System; D.E. Shaw Research, New York, 2015.

(49) Maestro-Desmond Interoperability Tools; Schrödinger LLC, New York, 2015.

(50) Bowers, K.J.; Chow, E.; Xu, H.; Dror, R.O.; Eastwood, M.P.; Gregersen, B.A.; Klepeis, J.L.; Kolossvary, I.; Moraes, M.A.; Sacerdoti, F.D.; Salmon, J.K.; Shan, Y.; Shaw, D.E. Scalable algorithms for molecular dynamics simulations on commodity clusters. in Proc. ACM/IEEE Conf. Supercomput. 2006.

(51) Phase; Schrödinger LLC, New York, 2015.

(52) Dixon S.L.; Smondyrev A.M.; Knoll E.H.,; Rao S.N.; Shaw D.E.; Friesner R.A. PHASE: A new engine for pharmacophore perception, 3D QSAR model development, and 3D database screening: 1. Methodology and preliminary results. J. Comput. Aided Mol. Des. 2006, 20, 647-671.

(53) Dixon S.L.; Smondyrev A.M.; Rao S.N. PHASE: A novel approach to pharmacophore modeling and 3D database searching. Chem. Biol. Drug Des. 2006, 67, 370-372 . 
Table of Contents Graphic:

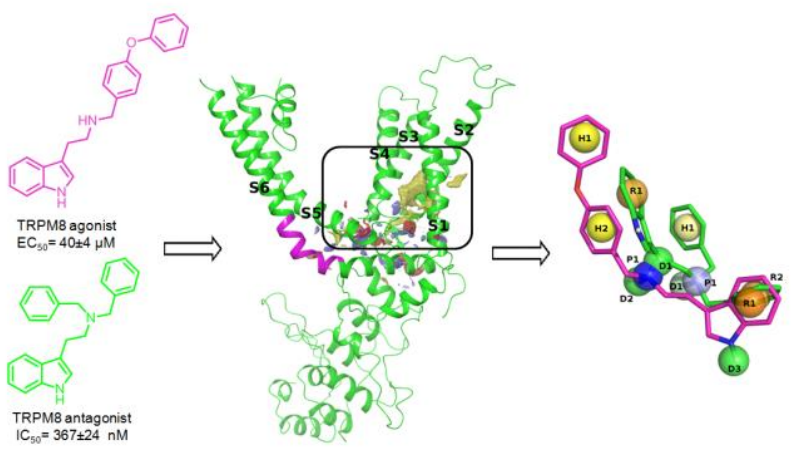

